\title{
On the representation of high latitude processes in the ORCA-LIM global coupled sea ice-ocean model
}

\author{
Ralph Timmermann ${ }^{\mathrm{a}, *}$, Hugues Goosse ${ }^{\mathrm{a}}$, Gurvan Madec ${ }^{\mathrm{b}}$, Thierry Fichefet ${ }^{\mathrm{a}}$, \\ Christian Ethe ${ }^{\mathrm{b}}$, Valérie Dulière ${ }^{\mathrm{a}}$ \\ a Institut d'Astronomie et de Géophysique Georges Lemaître, Univ. Catholique de Louvain, Chemin du Cyclotron 2 , \\ 1348 Louvain-la-Neuve, Belgium \\ b Laboratoire d'Océanographie Dynamique et de Climatologie (LODYC), 75252 Paris, France
}

Received 31 July 2003; received in revised form 17 December 2003; accepted 19 December 2003

Available online 28 January 2004

\begin{abstract}
The dynamic-thermodynamic Louvain-la-Neuve sea ice model (LIM) has been coupled to the OPA primitive equation ocean general circulation model. In the ORCA2-LIM configuration, the model is run on a global domain with $2^{\circ}$ mean resolution. Model runs are forced with a combined dataset consisting of daily NCEP/NCAR reanalysis data and various climatologies. The model's performance is evaluated with respect to the representation of sea ice and the high latitude oceans. The annual cycle of sea ice growth and decay is realistically captured in both hemispheres, with ice extent, thickness and drift in close agreement with observations. The location of the main sites of deep convection (Labrador and Greenland Seas; continental shelves of marginal seas of the Southern Ocean) is well reproduced. Model deficiencies include a slight overestimation of summer ice extent in the Arctic, and a significant underestimation of multi-year ice in the Weddell Sea. Furthermore, the width of the Arctic Ocean Boundary Current and the Antarctic Circumpolar Current is overestimated. Sensitivity studies indicate that the use of the combined forcing dataset is crucial to achieve a reasonable summer sea ice coverage and that the direct use of the NCEP/ NCAR wind stress data leads to an overestimation of sea ice drift velocities. A restoring of sea surface salinity is necessary to avoid spurious open ocean convection in the Weddell Sea.
\end{abstract}

(C) 2004 Elsevier Ltd. All rights reserved.

\footnotetext{
* Corresponding author. Address: Stiftung Alfred-Wegener-Institut für Polar-und Meeresforschung, Postfach 1201 61, 27515 Bremerhaven, Germany. Tel.: +49-471-4831-1796; fax: +49-471-4831-1797.

E-mail address: rtimmermann@awi-bremerhaven.de (R. Timmermann).
} 


\section{Introduction}

Seasonal and interannual variations of the sea ice cover represent some of the most pronounced signals of variability in the Earth's climate system. Freezing and melting of sea ice control the amount and location of deep and bottom water formation in the marginal seas of the Southern Ocean; sea ice export from the Arctic Ocean appears to modulate the occurrence and intensity of North Atlantic deep convection. The importance of these processes for the global thermohaline circulation and the difficulties in directly observing them have motivated numerous modelling studies on ocean circulation, sea ice-ocean interaction and the variability of these processes on seasonal and interannual time scales.

Since more than a decade now, dynamic-thermodynamic sea ice models have been coupled to regional oceanic general circulation models (OGCMs) in the Arctic (e.g. Häkkinen and Mellor, 1992; Zhang et al., 1998) and the Antarctic (e.g. Häkkinen, 1995; Marsland and Wolff, 2001; Timmermann et al., 2002a,b). Early global models typically had a very coarse resolution (e.g. Kim and Stössel, 1998; Goosse and Fichefet, 1999) and often had difficulties to achieve an overall realistic simulation of sea ice coverage and hydrography. Recently, however, global coupled sea ice-ocean models with a resolution of down to $1 / 4^{\circ}$ have been developed and used for regional studies in the high latitudes (e.g. Zhang and Semtner, 2001).

The Louvain-la-Neuve sea ice model (LIM; Fichefet and Morales Maqueda, 1997, 1999), which has been used as the sea ice component of the global CLIO model for studies of Arctic and Antarctic sea ice variability (e.g. Fichefet et al., 2003b), has now been coupled to the OPA ocean general circulation model (Madec et al., 1999). OPA in uncoupled mode has been extensively validated in a regional domain in the tropics (Vialard et al., 2001). Coupled to atmospheric GCMs, OPA has been used in process studies (e.g. Guilyardi et al., 2001; Raynaud et al., 2000), paleoclimate simulations (Braconnot et al., 1999) and climate change scenarios (e.g. Barthelet et al., 1998; Friedlingstein et al., 2001). However, no special interest to the polar regions was paid. An approach towards using the coupled model as a research tool for high latitude oceans and an assessment of its performance is presented in this paper. The following section describes the model components and the coupling strategy. In Section 3, the model is validated against observations of sea ice concentration, thickness and drift, as well as some crucial aspects of high latitude circulation and hydrography. Section 4 demonstrates the model's sensitivity to the choice of atmospheric forcing fields. A discussion and a summary conclude the paper.

\section{Model description}

\subsection{Ocean model}

The ocean component of the ORCALIM global coupled ice--ocean model is based on version 8.2 of the hydrostatic, primitive equation ocean model OPA (Océan Parallélisé; Madec et al., 1999; see full documentation at http://www.lodyc.jussieu.fr/opa/). OPA is a finite difference OGCM with a free sea surface and a non-linear equation of state in the Jackett and McDougall (1995) formulation. 
In the ORCA2-LIM configuration, lateral tracer mixing is done along isopycnals. Eddyinduced tracer advection is parameterized following Gent and McWilliams (1990) with the coefficients decreased in the tropics, i.e. between $20^{\circ} \mathrm{N}$ and $20^{\circ} \mathrm{S}$. Momentum is mixed along model level surfaces using coefficients varying with latitude, longitude and depth.

Vertical eddy diffusivity and viscosity coefficients are computed from a level-1.5 turbulent closure scheme based on a prognostic equation for the turbulent kinetic energy. This parameterization has been developed for the atmosphere by Bougeault and Lacarrère (1989), adapted for the ocean by Gaspar et al. (1990) and embedded in OPA by Blanke and Delecluse (1993). Double diffusive mixing (i.e. salt fingering and diffusive layering) is computed following Merryfield et al. (1999). In locations with a statically unstable stratification, a value of $100 \mathrm{~m}^{2} \mathrm{~s}^{-1}$ is assigned to the vertical eddy coefficients for momentum and tracers.

The Beckmann and Döscher (1997) bottom boundary layer scheme ensures an improved representation of dense water spreading over topography in this geopotential-coordinate model.

\subsection{Sea ice model}

The sea ice component of ORCALIM is the Louvain-la-Neuve sea ice model (LIM), which is a dynamic-thermodynamic model specifically designed for climate studies. It has previously been used in the CLIO global coupled sea ice-ocean model (Goosse and Fichefet, 1999). A brief description of the model is given here; further details can be found in the descriptions by Fichefet and Morales Maqueda (1997, 1999).

The thermodynamic part of LIM uses a three-layer model (one layer for snow and two layers for ice) for sensible heat storage and vertical heat conduction within snow and ice. Vertical and lateral sea ice growth/decay rates are obtained from energy budgets at the upper and lower surfaces of the snow-ice cover, and at the surface of leads present within the ice pack. At the upper surface, a prognostic treatment of the temperature in a very thin surface layer is used. The effect of the subgrid-scale snow and ice thickness distributions is accounted for through an effective thermal conductivity, which is computed by assuming that the snow and ice thicknesses are uniformly distributed between zero and twice their mean value over the ice-covered portion of the grid cell. Storage of latent heat inside the ice resulting from the trapping of shortwave radiation by brine pockets is taken into account. Surface albedo is parameterized following Shine and Henderson-Sellers (1985), combined with the modifications for clear and overcast conditions recommended by Greenfell and Perovich (1984), and depends on the state of the surface (frozen or melting) and the thickness of the snow and ice covers. When the load of snow is large enough to depress the snow-ice interface under the water level, seawater is supposed to infiltrate the entirety of the submerged snow and to freeze there, forming a snow ice cap.

The ice concentration, the snow volume per unit area, the ice volume per unit area, the snow enthalpy per unit area, the ice enthalpy per unit area and the brine reservoir per unit area are advected with the ice drift velocity $u_{i}$. The velocity field is determined from a momentum balance considering sea ice as a two-dimensional continuum in dynamical interaction with atmosphere and ocean. The viscous-plastic constitutive law proposed by Hibler (1979) is used for computing internal stress within the ice for different states of deformation. The ice strength is assumed to be a function of the ice thickness and concentration (Hibler, 1979). After a series of sensitivity 
experiments in the ORCA2-LIM configuration, we chose the ice strength parameter to be $P^{*}=20,000 \mathrm{Nm}^{-2}$.

The model includes a parameterization for the formation of leads due to shearing deformation following Stern et al. (1995). To account for small-scale fluctuations of sea ice drift which further contribute to the opening of leads (Heil and Hibler, 2002), we use a rather high value of $1.0 \mathrm{~m}$ for the lead closing parameter $h_{0}$.

The model equations are solved numerically as an initial value-boundary value problem by using finite difference techniques. A staggered spatial grid of type B is utilised. The heat diffusion equation for snow and ice is solved using a fully implicit numerical scheme, which avoids the development of numerical instabilities when the snow or ice thickness becomes very small. The ice momentum balance is treated basically as in Hibler (1979), the two main differences being that the oceanic drag term is not linearized and a simultaneous underrelaxation technique is systematically applied. A no-slip condition is imposed on land boundaries.

The advective terms in the continuity equations for the prognostic variables are computed using the forward time marching scheme of Prather (1986). This method is based on the conservation of the second-order moments of the spatial distribution of the advected quantities within each grid cell. It preserves the positiveness of the transported variables and yields very small diffusion. For a horizontal grid with a relatively coarse resolution (like the one used here), it allows to determine the location of the ice edge with a higher accuracy than the more conventional upstream schemes do.

The equations for ice motion and transport are written in curvilinear, orthogonal coordinates, which allows for model setups on a large variety of horizontal grids. Here, the model runs on the same grid as the ocean model (see below).

\subsection{Ice-ocean coupling}

The coupling between the sea ice and ocean models uses the equations given by Goosse and Fichefet (1999). Momentum exchange at the ice-ocean interface is derived from the velocity difference using a quadratic bulk formula with a drag coefficient of $5 \times 10^{-3}$. The ocean velocities of the uppermost grid box are assumed to be surface velocities; therefore, no turning angle is applied. Following McPhee (1992), the ice-ocean heat flux is assumed to be proportional to the difference between the surface temperature and the temperature at the freezing point (which in turn depends on the sea surface salinity), and the friction velocity at the ice-ocean interface. Fresh water (salinity) fluxes between the ice and the ocean assume constant salinities of 6 psu for sea ice and 0 psu for snow. Solar radiation penetrates the ocean surface layers with an exponential extinction profile.

The ocean model is run with a time step of $5760 \mathrm{~s}$ (which converts to 96 min, or 15 time steps per day) and coupled bidirectionally to the ice model every five time steps.

\subsection{Configuration on a global grid}

In the ORCA2-LIM configuration, the model domain extends from $78^{\circ} \mathrm{S}$ to $90^{\circ} \mathrm{N}$. The model uses a tripolar grid with $2^{\circ}$ zonal resolution, and a meridional resolution varying from $0.5^{\circ}$ at the equator to $2^{\circ} \cos \phi$ south of $20^{\circ} \mathrm{S}$ (Fig. 1). The grid features two points of convergence in the 


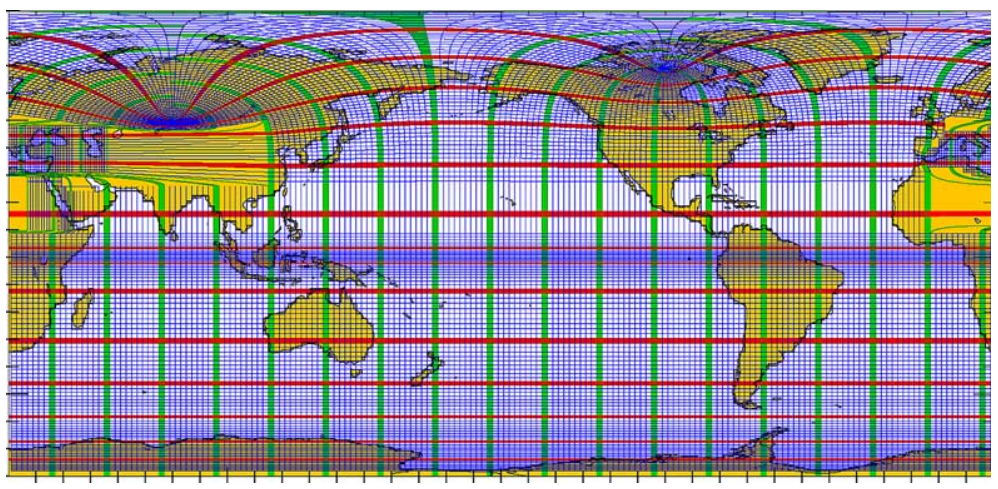

Fig. 1. The ORCA2-LIM model grid, projected on a global map of Earth. Blue lines denote grid cell boundaries. Grid cells are colored in red and green every 10 boxes in meridional and zonal direction, respectively. Note the local mesh refinements near the equator, and in the Mediterranean, Red, Black and Caspian Seas.

Northern Hemisphere, both situated on continents. Minimum resolution in high latitudes is about $65 \mathrm{~km}$ in the Arctic and $50 \mathrm{~km}$ in the Antarctic. Local mesh refinements are applied to the Mediterranean, Red, Black and Caspian Seas. None of them appears to be of particular importance for the study of high latitude climate, but the fine resolution is needed in order to have their local circulation and their role in the World Ocean's circulation considered correctly.

Bottom topography and coastlines are derived from the study of Smith and Sandwell (1997), complemented by the ETOPO5 dataset. Vertical discretization uses $30 z$-levels in the water column, with 10 levels in the top $100 \mathrm{~m}$.

\subsection{Initialization and forcing}

Model runs are initialized using the January data from the Polar Science Center Hydrographic Climatology (PHC; Steele et al., 2001). An initial sea ice thickness of $3 \mathrm{~m}$ in the Arctic and $1 \mathrm{~m}$ in the Antarctic is prescribed in regions with a sea surface temperature below $0{ }^{\circ} \mathrm{C}$. An initial snow cover with a thickness of $0.5 \mathrm{~m}$ in the Arctic and $0.1 \mathrm{~m}$ in the Antarctic is assumed.

Atmospheric forcing fields are a combined dataset consisting of the NCEP/NCAR daily reanalysis data of $10 \mathrm{~m}$ wind speed and $2 \mathrm{~m}$ temperature (Kalnay et al., 1996), and monthly climatologies of relative humidity (Trenberth et al., 1989), total cloudiness (Berliand and Strokina, 1980) and precipitation (Xie and Arkin, 1996). A quadratic bulk formula with a drag coefficient of $2.25 \times 10^{-3}$ is used to compute the surface wind stress. Surface fluxes of sensible and latent heat are computed using empirical parameterizations described by Goosse (1997). Evaporation/sublimation is derived from the latent heat flux. River runoff rates are prescribed using the climatological Baumgartner and Reichel (1975) dataset combined with a mean seasonal cycle derived from the Global Runoff Data Centre (GRDC, 2000) data. To avoid spurious model drift, a restoring of sea surface salinity (SSS) towards the seasonal PHC dataset is applied with a time scale of $60 \mathrm{~d}$.

Given that reliable sea ice observations are scarce before the late seventies, forcing data from the period 1977-1999 are used for this study. The first pass of this dataset, already run in fully 
coupled mode, is used to obtain a quasi-stationary seasonal cycle; results from the second pass are used to assess the model's performance.

Of course, with only 23 years of spinup, the model is not run "to equilibrium" in a strict sense. However, in contrast to the low latitude ocean, in which deep water properties change on time scales of decades to centuries, communication between the surface and the deep ocean in polar regions occurs as part of the seasonal signal or an interannual variability. So, in order to investigate ice-ocean interaction, the model does not need to be integrated for hundreds of yearsprovided that areas that feature a much slower variability are initialized close to reality.

\section{Model results and validation}

\subsection{Sea ice extent}

\subsubsection{Seasonal and interannual variability}

Time series of simulated sea ice extent (i.e. the area with ice concentrations $>15 \%$ ) and volume (Fig. 2) indicate that the model reaches a quasi-stationary seasonal cycle after only a few years of initial adjustment. While the seasonal cycle and a pronounced interannual variability are clearly visible, large trends can be found in neither hemisphere. Over the complete integration, we find linear trends of $-4400 \mathrm{~km}^{2} \mathrm{yr}^{-1}$ the Arctic and of $7900 \mathrm{~km}^{2} \mathrm{yr}^{-1}$ in the Antarctic sea ice extent. However, this includes the initial adjustment phase and extends over two passes of the same
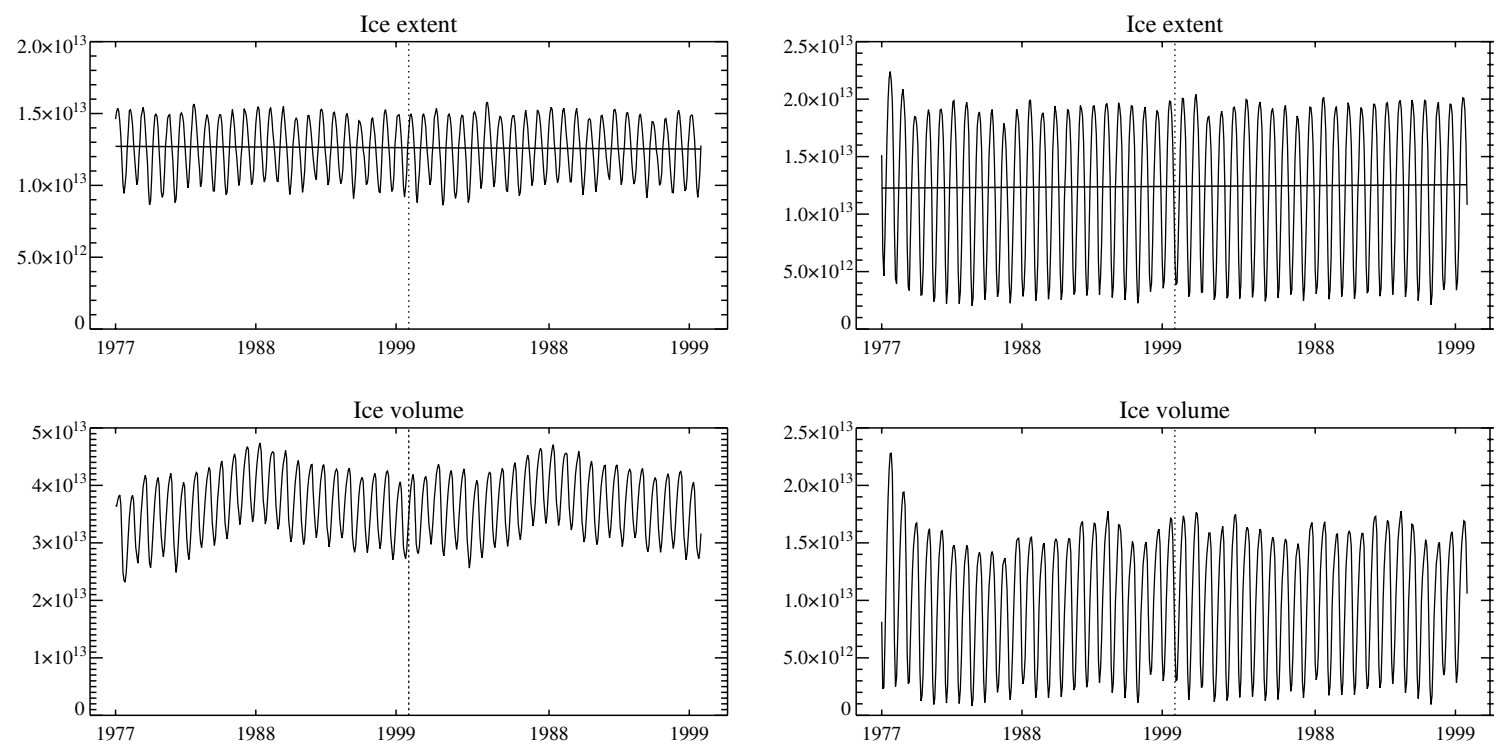

Fig. 2. Time series of Arctic (left) and Antarctic (right) sea ice extent $\left(\mathrm{m}^{2}\right)$ and volume $\left(\mathrm{m}^{3}\right)$ in the ORCA2-LIM reference simulation. Two passes of the 1977-1999 period are displayed, separated by the dashed line. The thin solid line indicates the linear trend in the ice extent. 
forcing dataset, so it cannot be compared to observed trends and does not allow for a statement about natural climate variability.

Considering the annual mean ice extent only during the second pass of the 1977-1999 period, we find linear trends of $-640 \mathrm{~km}^{2} \mathrm{yr}^{-1}$ in the Arctic and: $+900 \mathrm{~km}^{2} \mathrm{yr}^{-1}$ in the Antarctic. For the period 1977-1999, this results in an overall decrease of annual mean ice extent of $0.1 \%$ in the Arctic and an increase of $0.2 \%$ in the Antarctic, neither of which is really significant. For the Arctic, this is in clear contradiction to analyses derived from remote sensing data which indicate a decline of about $34,000 \mathrm{~km}^{2} \mathrm{yr}^{-1}$ (2.8\% per decade) in Arctic sea ice extent (Parkinson et al., 1999) since the late seventies. We attribute this discrepancy to the fact that the model has been spun up using the 1977-1999 period of atmospheric forcing data, so that at the beginning of the second pass, it is adjusted to the conditions of the late 1990s.

Time series of the mean seasonal cycle of the ice extent (Fig. 3) feature a good agreement with observations derived from satellite passive microwave recordings. This is especially true in the Arctic, where errors in the extent are smaller than $10 \%$ for most of the year. Compared to the observed seasonal cycle, sea ice retreat is delayed by roughly 20 days, so that the minimum sea ice extent is overestimated by about $14 \%$.

In contrast to the Arctic, the Antarctic summer sea ice extent is underestimated by about $40 \%$ (see below for a discussion of the reasons and the region affected), while winter sea ice extent again is in very good agreement with observations. While the time of the summer minimum ice extent is realistically reproduced, sea ice growth and decay appear to be too fast; the sea ice extent maximum is reached (and passed) about a month too soon.

Time series of monthly anomalies (i.e. differences of monthly means from the mean seasonal cycle; Fig. 4) indicate that the model captures only part of the ice extent variability. Fluctuations of Arctic ice extent occurring on time scales of a few months are not always reproduced correctly; sometimes not even with the correct sign. However, anomalies occurring on time scales from several months to one or two years, e.g. the increased Arctic ice extent in 1982/1983, the negative trend in ice extent over the period 1993-1996, but also the pronounced positive ice extent anomaly in the Arctic summer of 1996, are reproduced quite realistically. In the Antarctic, we find a good representation of the most pronounced anomalies, even on time scales of several months. Specifically, the unusually low summer ice extents in the austral summers 1979/1980, 1986/1987 and 1996/1997 are all well reproduced. However, compared to the observed minima and maxima, the
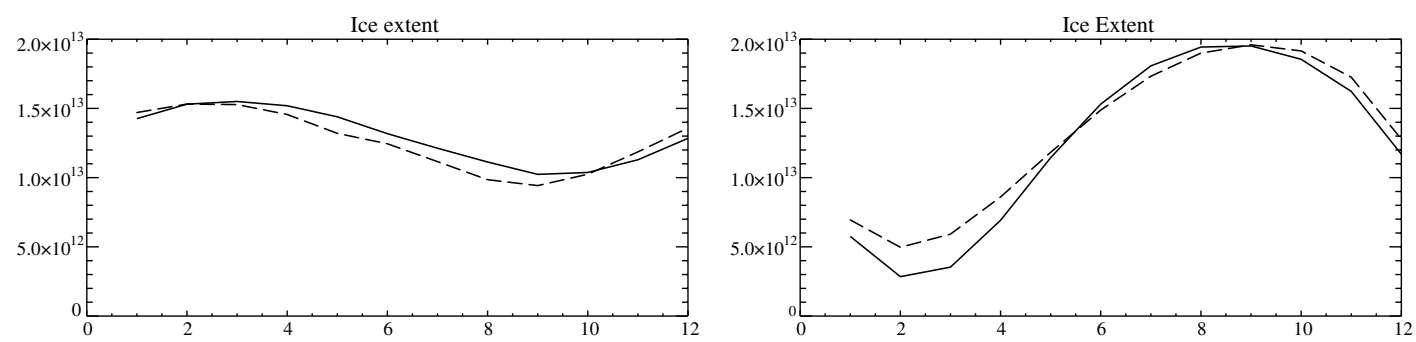

Fig. 3. Time series of seasonal mean Arctic (left) and Antarctic (right) sea ice extent $\left(\mathrm{m}^{2}\right)$ in the ORCA2-LIM reference simulation (solid) and in observations derived from satellite passive microwave recordings (dashed; Comiso, 1999; Heygster et al., 1996). 

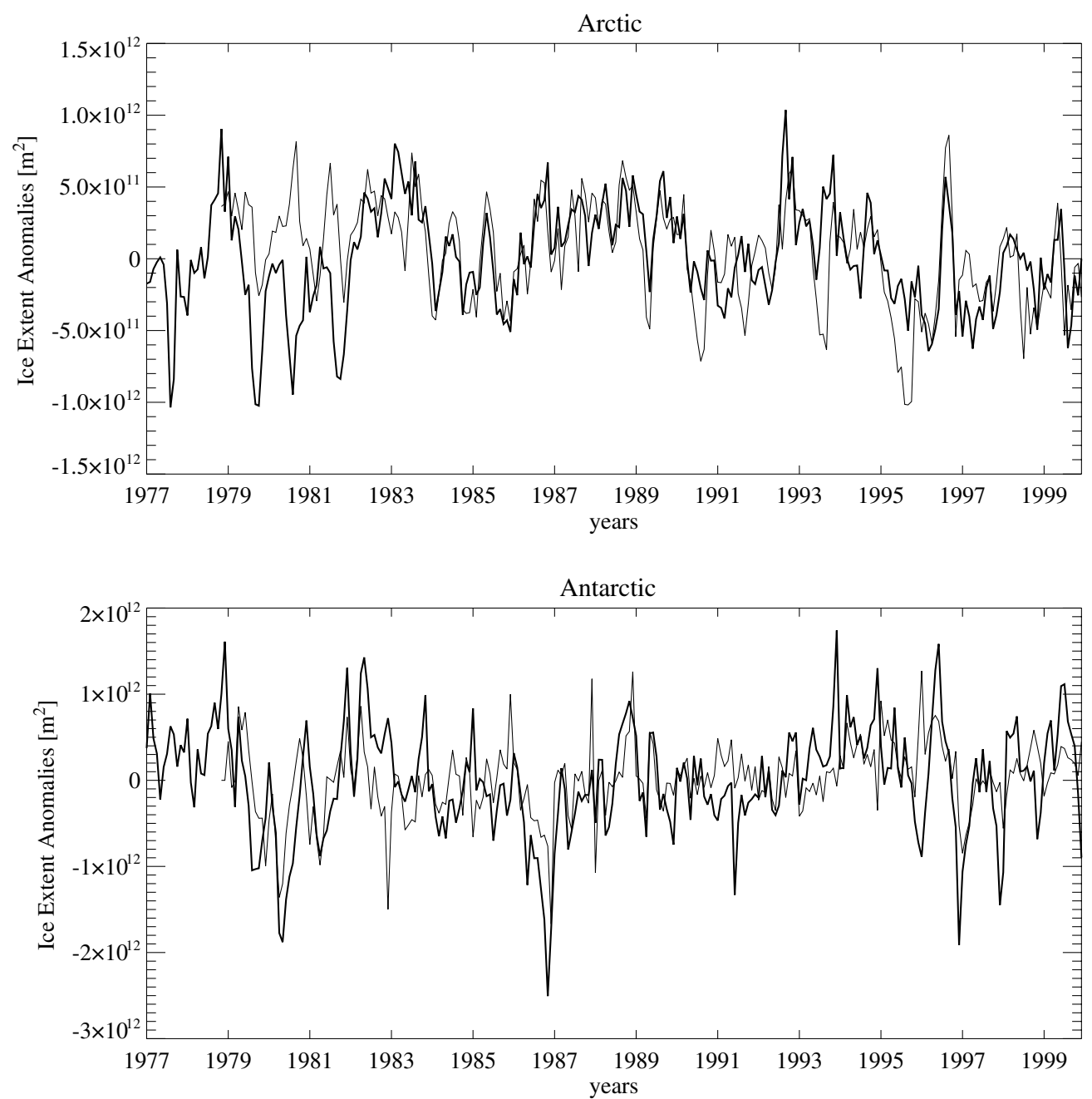

Fig. 4. Time series of monthly mean anomalies (i.e. differences of individual monthly means from the mean seasonal cycle) of sea ice extent $\left(\mathrm{m}^{2}\right)$ for the Arctic (top) and Antarctic (bottom) in the ORCA2-LIM reference simulation (bold lines) and in observations derived from satellite passive microwave recordings (thin lines; Comiso, 1999; Heygster et al., 1996).

model representations of these events are often shifted by one or two months. Correlation coefficients between simulated and observed anomaly time series are 0.49 for both hemispheres.

Generally, results of the analysis of monthly mean ice extent anomalies in ORCA2-LIM are very similar to the findings for anomalies of the ice covered area simulated by the CLIO global coupled sea ice-ocean model, which was forced with the same combination of atmospheric data (Fichefet et al., 2003b). Specifically, the discrepancies in the 1979-1981 Arctic ice extent anomalies are featured in both models. Whether these deficiencies are due to the fact that none of the forcing fields related to atmospheric humidity contains any interannual variability will be investigated in a sensitivity study further down this paper. 


\subsubsection{Regional distribution}

A comparison of the simulated sea ice distribution in the Arctic (Fig. 5) with observations derived from passive microwave data using the Bootstrap algorithm (Comiso, 1999) reveals a significant overestimation of sea ice extent in the Kara Sea and in Baffin Bay in summer. Although it is not pronounced in the model climatology, the Great Siberian Polynya is present in most of the years, but its width tends to be underestimated. In winter, the model slightly overestimates ice extent in the Barents and Greenland Seas, and does not reproduce the Odden Ice Tongue visible in the remote sensing data. Furthermore, it overestimates the width of the ice stream along the east coast of Greenland and in Denmark Strait, which leads to a spurious blocking of ice drift by the Iceland coast.

We mostly attribute these deficiencies to the relatively coarse model resolution: In the model, Denmark Strait is resolved by only three grid cells which clearly is not enough to capture a narrow ice stream. The complete Odden/Nordbukta structure (see, e.g. Comiso et al., 2001) would only cover 3-4 grid cells in zonal extent, so neither of the hypothesized mechanisms for odden formation (e.g. cold air outbursts, instabilities of the East Greenland Current) is covered in enough
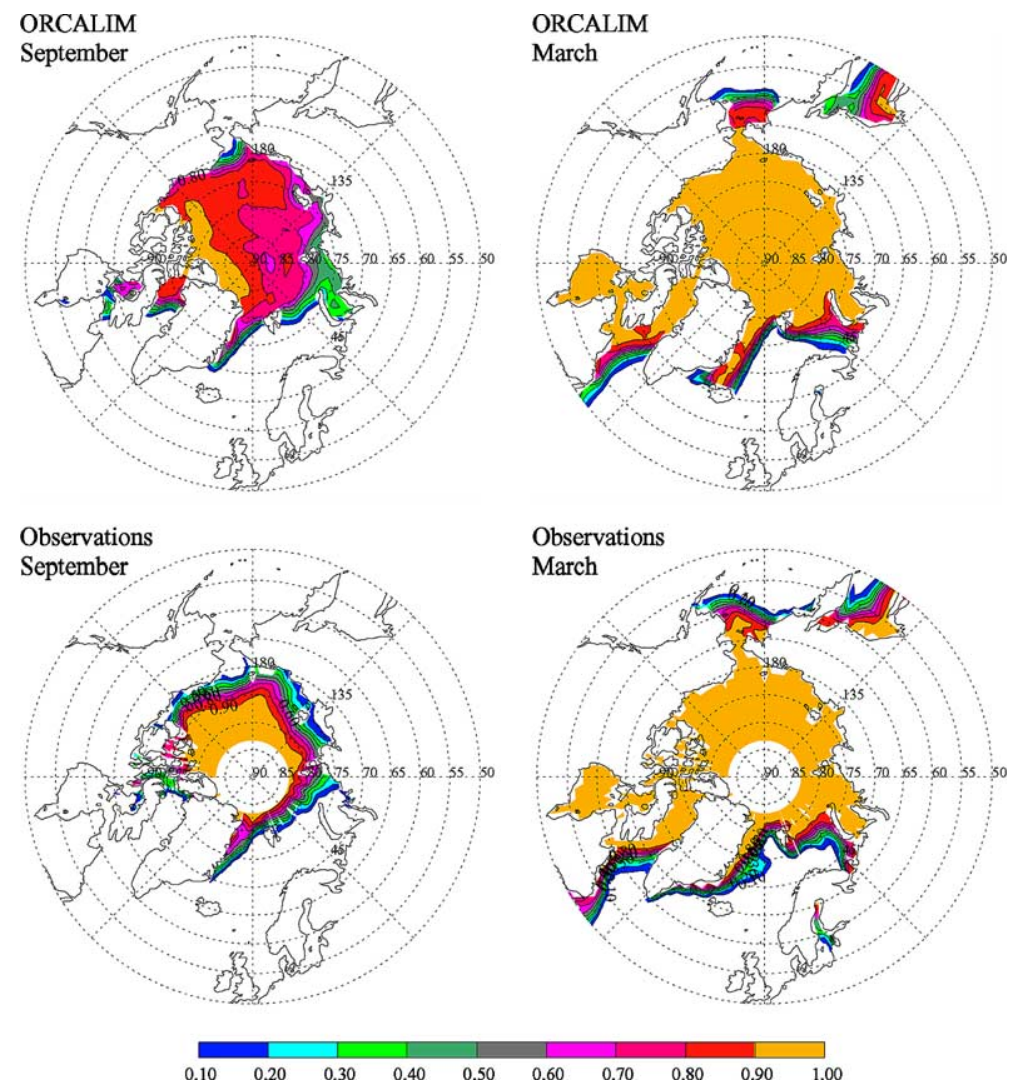

Fig. 5. Simulated (top) and observed (bottom) seasonal mean ice concentrations for September (left) and March (right), indicating the minimum and maximum ice coverage in the Arctic. Contour interval is $10 \%$. Observed fields are derived from the dataset of Comiso (1999). 
detail. An analysis of near-surface ocean hydrography (see Sections 3.4 and 3.5) indicates that the overestimation of ice extent in the Barents Sea is due to an underestimation of vertical oceanic heat flux rather than due to a poor representation of the transport of Atlantic water into the Barents Sea.

We also note that the percentage of open water appears to be significantly overestimated in summer. In contrast to the ice extent, the computation of ice concentration within the ice-covered area is subject to large uncertainties both in the model and in the remote sensing data - bootstrap sea ice concentrations are reported to have an inaccuracy of $15-20 \%$ in summer (Comiso et al., 1997; Cavalieri et al., 1999).

In the Antarctic, the simulated minimum sea ice distribution (Fig. 6) features a lack of sea ice near the tip of the Antarctic Peninsula and along the east Antarctic coast. We attribute the first
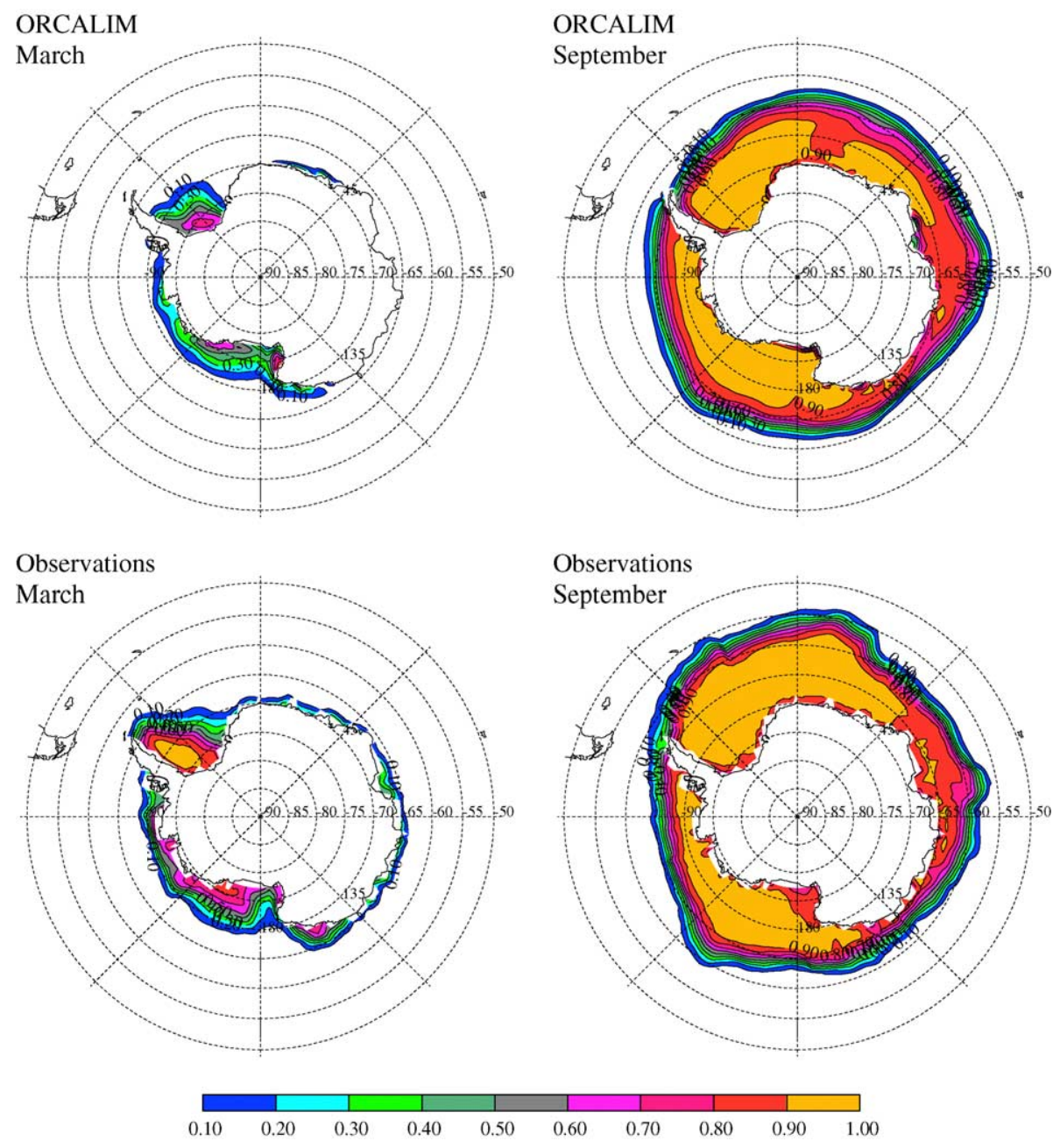

Fig. 6. Simulated (top) and observed (bottom) seasonal mean ice concentrations for March (left) and September (right), indicating the minimum and maximum ice coverage in the Southern Ocean. Contour interval is $10 \%$. Observed fields are derived from the dataset of Comiso (1999). 
mainly to a poor representation of the Antarctic Peninsula in the atmospheric forcing fields (Windmüller, 1997) and the latter to the model's relatively coarse resolution.

During austral winter, Antarctica is enclosed by a compact sea ice cover. Each of the three subpolar gyres leads to a northward spreading of sea ice. For the Kerguelen and Ross Gyres, this feature is captured very realistically. In contrast to this, winter ice extent is slightly underestimated in the Weddell Sea sector, while in the Amundsen and Bellingshausen Seas, winter ice cover extends too far northward. Northward sea ice extent is limited by the westerly winds and the position of the Antarctic Circumpolar Current (ACC) which, even in winter, has surface temperatures above the freezing point and acts as a permanent heat source. Its course is largely determined by bottom topography which, especially in a $z$-coordinate model at $2^{\circ}$ mean resolution, does not necessarily capture all details of the real bathymetry.

\subsection{Sea ice thickness}

Simulated winter sea ice thickness in the Arctic (Fig. 7) features a pronounced ice thickness gradient from about $2 \mathrm{~m}$ in the western Siberian Shelf Sea to $4 \mathrm{~m}$ at the North Pole and more than $6 \mathrm{~m}$ off the Canadian Archipelago. Comparison to data derived from submarine ULS measurements (Bourke and Garrett, 1987; Bourke and McLaren, 1992) indicates a good agreement of the large-scale ice thickness distribution. However, the model appears to overestimate ice thickness on the Siberian shelf by about $1 \mathrm{~m}$ in the Kara Sea, $1.5 \mathrm{~m}$ in the Laptev Sea and $2 \mathrm{~m}$ in the East Siberian Sea. The overestimation of ice extent in the Barents Sea (see previous section) is naturally connected to an overestimated ice thickness in this region. Furthermore, the spurious blocking of ice drift by the Iceland coast causes an artificial local ice thickness maximum in that area.

Compared to the data of Rothrock et al. (2003), ice thickness in the Canadian Basin appears to be overestimated. Consequently, the ice thickness gradient between the Eurasian and Canadian Basins that appears to be rather realistic when model data are compared to the distribution presented by Bourke and Garrett (1987) seems to be overestimated when compared to the more recent dataset of Rothrock et al. (2003). If the difference between the two observational datasets is

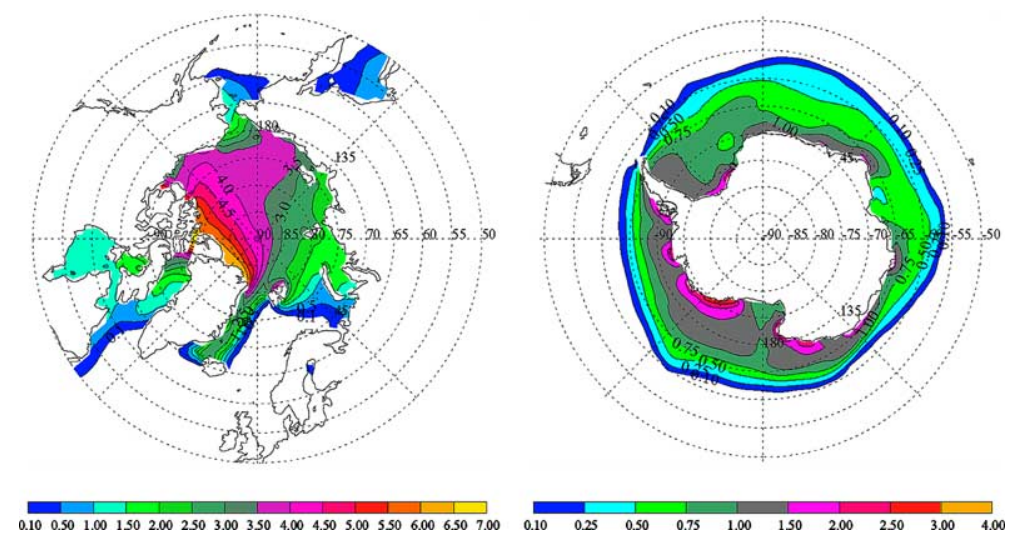

Fig. 7. Simulated winter mean ice thickness in the Arctic (January, left) and the Antarctic (September, right). Note the non-linear contour interval for the Antarctic. 
the signature of an interannual variability, this variability is not represented in the model. However, the model does reproduce the rapid thinning after 1988 (cf. the ice volume time series in Fig. 2) that has been suggested by Tucker et al. (2001).

The simulated sea ice thickness distribution in the Antarctic features a typical winter sea ice thickness between 0.5 and $1 \mathrm{~m}$ in the central Weddell Sea, and a pronounced meridional gradient along the Greenwich Meridian; ice thickness does hardly exceed the equilibrium thickness that can be achieved by purely thermodynamic sea ice growth (Harder and Lemke, 1994). In the Ross Sea, we find a reduced ice thickness in the region around the Ross Polynya which is a consistently observed feature in this sector (Jacobs and Comiso, 1989). A tongue of thick ice (maximum thickness $>2.5 \mathrm{~m}$ ) extends from the Amundsen Sea into the eastern Ross Sea, again in agreement with observations by Jacobs and Comiso (1989).

For a quantitative validation of the sea ice thickness in the Atlantic sector of the Southern Ocean, we use measurements from upward looking sonars (ULS; Strass and Fahrbach, 1998; Harms et al., 2001) which were deployed on the line Kapp Norvegia-Joinville Island and along the Greenwhich Meridian (Fig. 8). Comparison of monthly mean ice draft on the ULS positions
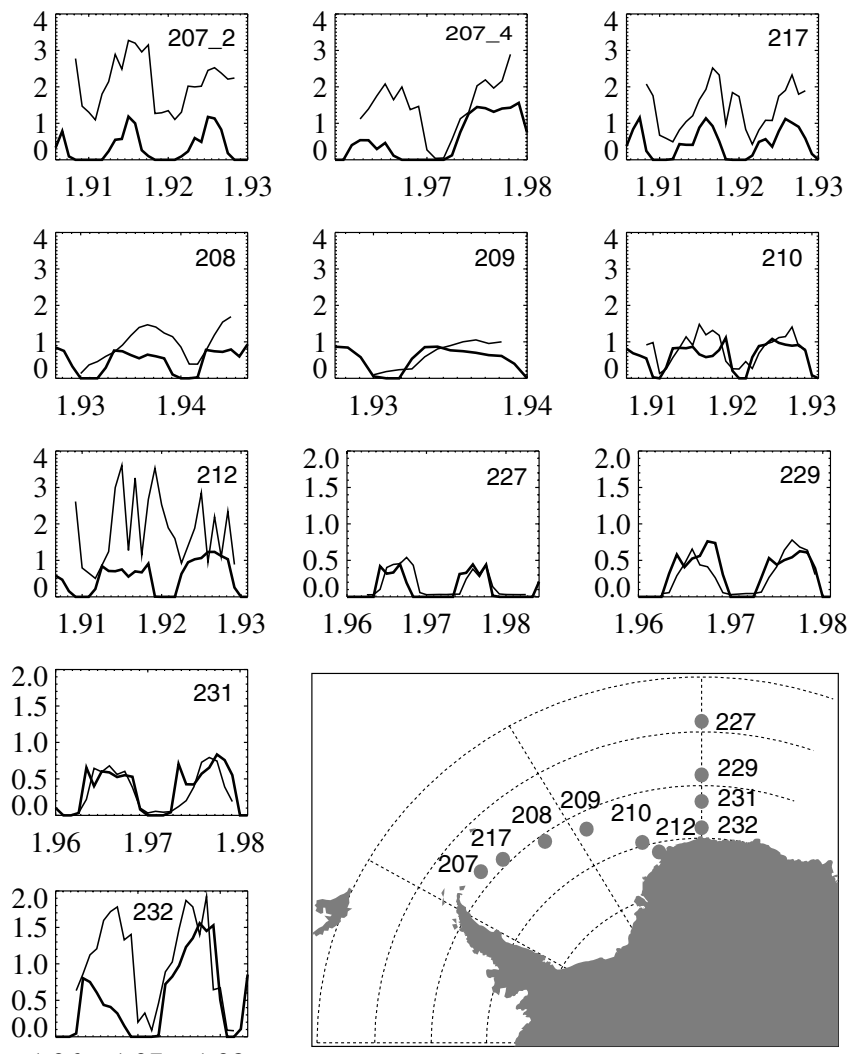

Fig. 8. Simulated (bold) and observed (thin) time series of monthly mean sea ice thickness at 10 ULS mooring sites in the Atlantic sector of the Southern Ocean. The map indicates the mooring positions and the respective AWI mooring numbers. 
indicates that at the offshore mooring positions 209 and 210 in the central and eastern Wedell Sea and along the Greenwich meridian the model is in good agreement with observations. However, ice thickness is significantly underestimated for the near-coast positions 212 and 232 in the eastern, and for positions 207, 217 and 208 in the western Weddell Sea.

We attribute this to a combination of reasons: The first one is related to the representation of sea ice dynamics in this coarse resolution model. Both in nature and in the model, sea ice is deformed in case of onshore winds. However, relevant scales for this process are much smaller than the grid size, so that a ULS point measurement directly adjacent to the coast (as is the case for positions 212 and 232) can hardly be reproduced by a value interpolated between the grid-cell wide averaged model ice thicknesses. The underestimation of ice volume in the western Weddell Sea (AWI moorings 207 and 217) can be attributed to the overestimation of melting due to a warm bias in the forcing data for that region (see above) which does not allow for the formation of thick, multi-year ice. However, the underestimated ice thickness at position 208, which is located rather in the central than in the western Weddell Sea, indicates that the model generally tends to underestimate the dynamic thickening of Antarctic sea ice.

Generally, results are quite similar to those obtained by Fichefet et al. (2003a) using the CLIO model with a $1.5^{\circ}$ horizontal resolution. CLIO uses the same sea ice component as ORCA2-LIM; however, parameterizations for ice dynamics (ice strength parameter) and thermodynamics (lead closing parameter) for that study were slightly different.

\subsection{Sea ice drift}

The large-scale sea ice drift on either hemisphere (Fig. 9) reflects the general patterns of atmospheric and oceanic circulations. The mean ice drift field in the Arctic features the Beaufort Gyre, the divergent motion on the Siberian shelf, the Transpolar Drift, and the ice export through Fram Strait. Velocities of about $2 \mathrm{~cm} / \mathrm{s}$ in the Beaufort Gyre, 3-4 cm/s in the Transpolar Drift and about $10 \mathrm{~cm} / \mathrm{s}$ in Fram Strait correspond well with the mean ice motion derived from $85.5 \mathrm{GHz}$ SSM/I data (Emery et al., 1997).

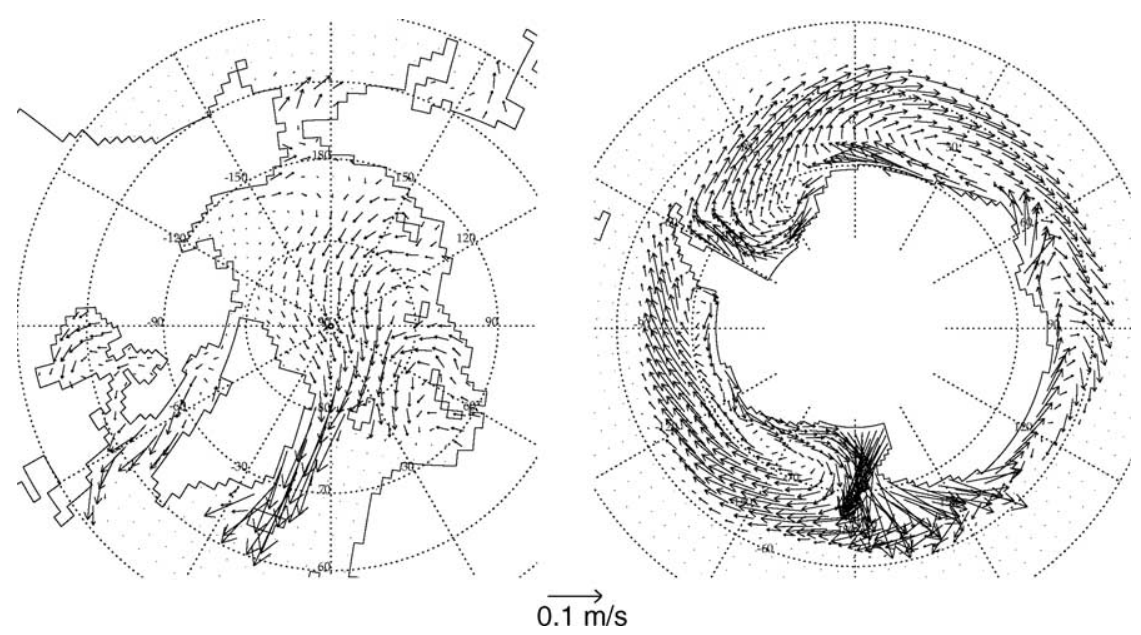

Fig. 9. Simulated long-term mean sea ice velocities in the Arctic (left) and the Antarctic (right). 
Ice export through Fram Strait amounts to $0.11 \mathrm{~Sv}$ in the 23 year mean with a standard deviation of $0.05 \mathrm{~Sv}$ for the time series of monthly means. This is at the upper limit of the range of estimates and well above the $0.092 \mathrm{~Sv}$ estimated for the period 1950-2000 by Vinje (2001) and the 0.075 Sv estimated for 1990-1995 by Kwok and Rothrock (1999) - the latter is true also when the ice export is averaged only over the period that has actually been analysed by Kwok and Rothrock (1999).

Simulated mean sea ice velocities in the Antarctic feature a westward drift of $5-10 \mathrm{~cm} / \mathrm{s}$ along with the coastal easterlies in the south, and the eastward drift of about $7 \mathrm{~cm} / \mathrm{s}$ following the westerly winds and the ACC further north. Between those bands, we find the classical Weddell, Ross and Kerguelen gyres with typical drift speeds of 2-5 cm/s. Again, ice drift speed and patterns agree very well with velocity fields derived from remote sensing data. Note the distinct drift channel in the western Ross Sea, exporting newly formed and relatively thin (Fig. 7) sea ice out of the southern Ross Sea into the subpolar Southern Ocean. After passing Cape Adare, part of the ice follows the coastal current westward along the Adelie Land coast, but most of it joins the west wind drift and the ACC.

A more quantitative analysis of sea ice drift will be part of a data assimilation effort that is currently going on at UCL.

\subsection{Ocean circulation}

Large-scale ocean surface circulation strongly resembles the sea ice drift pattern. In the Arctic (Fig. 10), the Beaufort Gyre, the Transpolar Drift, and the East Greenland Current are easily recognizable.
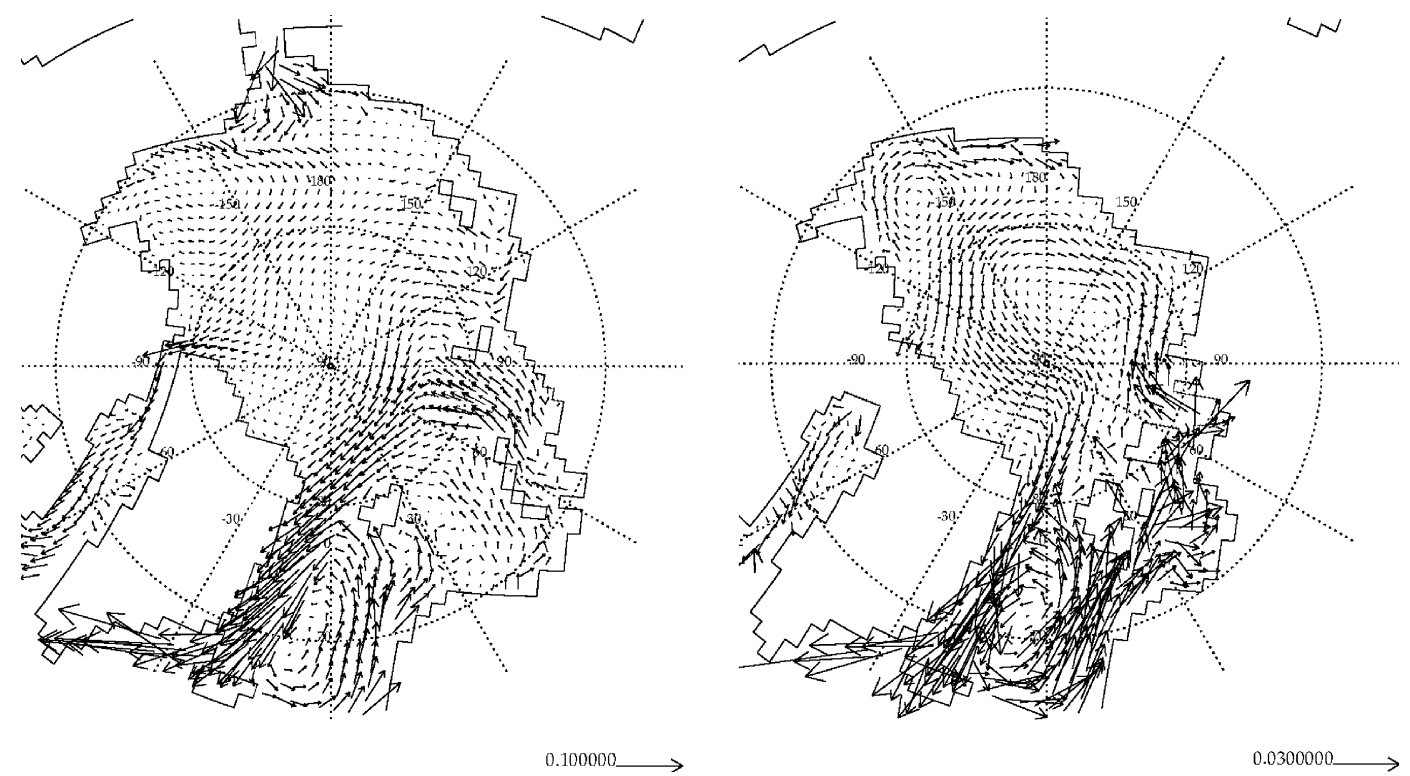

Fig. 10. Simulated mean ocean currents north of $64^{\circ} \mathrm{N}$ at the surface (left) and at $160 \mathrm{~m}$ depth (right). 
A prominent feature in the model ocean circulation between 100 and $1500 \mathrm{~m}$ depth is the Arctic Ocean Boundary Current that forms a cyclonic circulation along the margins of the Arctic Ocean Basin. This current is largely barotropic in the upper $500 \mathrm{~m}$; velocities decrease below this level, but the pattern is persistent. At $160 \mathrm{~m}$ depth, it recirculates north of the Beaufort Sea, southeast of Alpha Ridge (Fig. 10, right). Consistent with this, a closed anticyclonic cell is found in the Beaufort Sea and southern Canadian Basin. The recirculation and the associated anticyclonic cell are only present in the upper subsurface circulation; at $500 \mathrm{~m}$ depth, a single cyclonic cell occupying the whole Arctic Ocean Basin is found.

Not surprisingly, the model representation of these currents is much wider than in the coupled model of Zhang et al. (1999) that uses a grid with $18 \mathrm{~km}$ horizontal resolution. Furthermore, there is no recirculation at Lomonossov or Alpha Ridge.

The model does, however, capture the bifurcation of the North Atlantic inflow: While a northward current of $2.0 \pm 0.47 \mathrm{~Sv}$ enters the Arctic Ocean with the West Spitsbergen Current through Fram Strait, another 1.5 $\pm 0.75 \mathrm{~Sv}$ (net inflow) are found to pass through the Barents Sea opening and enter the Arctic Ocean further east through Barents or Kara Sea. Northward transport through Bering Strait varies between typical extremes of +1.5 and $-0.5 \mathrm{~Sv}$, with a mean of $0.4 \mathrm{~Sv}$ and the strongest inflow between May and July. While the simulated mean is about only $50 \%$ of the $0.83 \mathrm{~Sv}$ transport observed by Roach et al. (1995), the seasonal cycle is consistent. An outflow of $3.7 \pm 0.46 \mathrm{~Sv}$ through Fram Strait and a net outflow of $0.5 \pm 0.13 \mathrm{~Sv}$ through Davis Strait almost close the volume budget of the Arctic Ocean Basin. The residual $0.2 \mathrm{~Sv}$ volume inflow are roughly equally shared by river runoff and net precipitation.

In the Southern Ocean surface velocities (Fig. 11), we clearly see the Antarctic Coastal Current, the Weddell, Kerguelen and Ross Gyres, and the Antarctic Circumpolar Current (ACC). Vertically integrated transport through Drake Passage is $170 \mathrm{~Sv}$ in the 23 year average. This is significantly higher than the net transport of 134 Sv estimated by Whitworth and Peterson (1985),
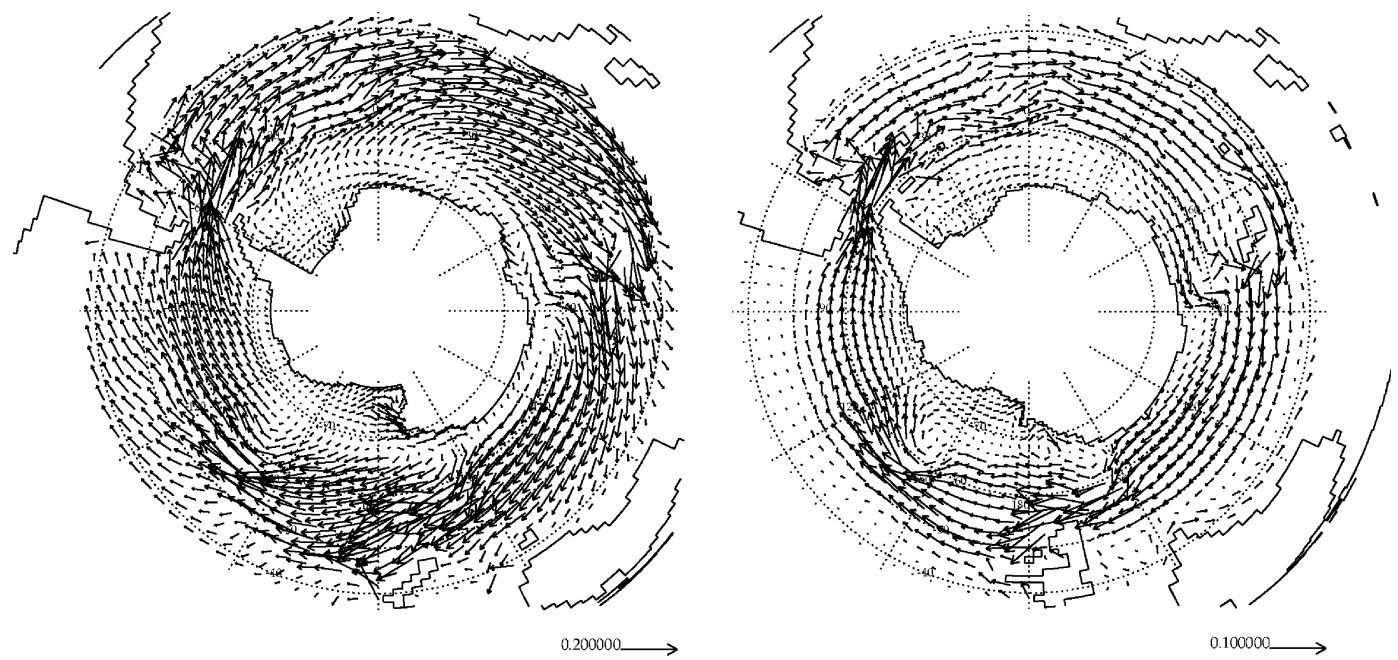

Fig. 11. Simulated mean surface currents south of $35^{\circ} \mathrm{S}$ at the surface (left) and at $1000 \mathrm{~m}$ depth (right). Only every other vector is drawn. 
and even exceeds the 10-20\% uncertainty that has been suggested by Cunningham et al. (2003). Maximum transport in the Weddell Gyre is $20 \mathrm{~Sv}$ and thus substantially lower than observationbased estimates of Fahrbach et al. (1994) and Schröder and Fahrbach (1999). While the model does not feature a clear double-cell structure as suggested by the BRIOS-model (Timmermann et al., 2002a), a constriction of the Weddell Gyre in the Maud Rise/Astrid Ridge region can be clearly seen at the $1000 \mathrm{~m}$ level. We also note that the Antarctic Circumpolar Current is too wide and extends too far southwards, inhibiting the development of a deep westward flowing coastal current in the Bellingshausen Sea and parts of the East Antarctic.

\subsection{Hydrography}

A map of climatological means of the mixed layer depth (as defined by the depth in which potential density exceeds surface density by more that $0.01 \mathrm{~kg} \mathrm{~m}^{-3}$ ) indicates the location of convection sites (Fig. 12). In the model Northern Hemisphere, deep convection occurs at the exit of the Labrador Sea and in the Nordic Seas. While the convective season lasts from December to April, peak activity is found in March. Typical mixing depths in this period are 400-500 $\mathrm{m}$ in the Labrador Sea, and 600-700 $\mathrm{m}$ in the Nordic Seas.

A comparison of Arctic Ocean subsurface temperatures after 45 years of integration (Fig. 13, left panel) to the annual mean derived from the PHC dataset (Fig. 13, right panel) reveals significant warming in the region off the Siberian shelf and in the Canadian Basin. The reason for this seems to be twofold: First, given that the total transport of warm Atlantic water into the region appears reasonable, deficiencies in the model ocean circulation cannot explain the overestimation of sea ice extent in the Barents Sea and the Siberian shelf region. Instead it is attributed
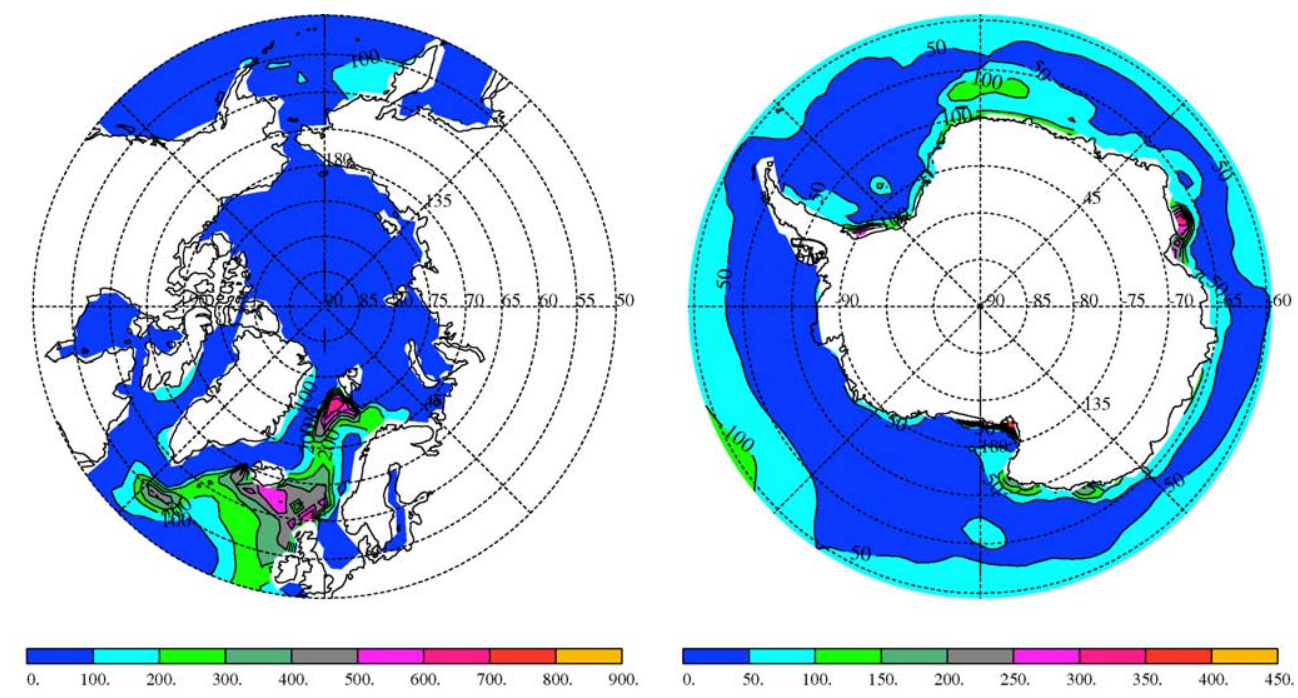

Fig. 12. Seasonal mean simulated mixed layer depths (as defined by the depth at which potential density exceeds surface density by more that $0.01 \mathrm{~kg} \mathrm{~m}^{-3}$ ) during the times of maximum convective activity, i.e. for March in the Arctic (left) and for June in the Antarctic (right). Contour intervals are $100 \mathrm{~m}$ for the northern and $50 \mathrm{~m}$ for the southern hemisphere. 


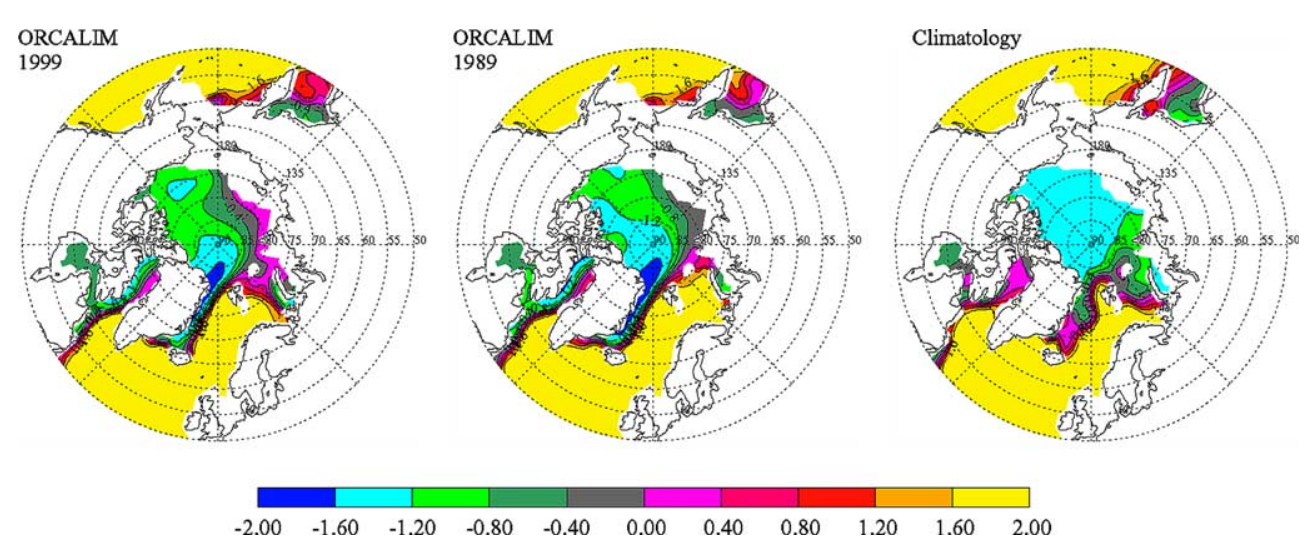

Fig. 13. Simulated annual mean potential temperature at $160 \mathrm{~m}$ depth for 1999 , i.e. after 45 years of integration (left), and 1989 (middle), and the annual mean observed temperature at the same level (right), derived from the PHC dataset (Steele et al., 2001). Temperatures exceeding $2{ }^{\circ} \mathrm{C}$ are still plotted in yellow.

to an underestimation of vertical mixing in the Barents and Kara Seas which allows for a spurious amount of heat to remain in the near-surface water column. Second, a subsurface warming in the Arctic Ocean in the early 1990s has been observed by Carmack et al. (1995) and was also found in a hindcast simulation by Gerdes et al. (2003). Indeed, the 1999 temperature distribution pictured in Fig. 13, left panel, represents a warm maximum in the model. Compared to annual means from the end of the 1980s (Fig. 13, middle panel), which are about $0.4{ }^{\circ} \mathrm{C}$ colder on the Siberian Shelf, we clearly see the temperature signal spreading along the continental slope. This signal is very similar in both passes of the 1977-1999 atmospheric forcing data, which indicates that at least part of the warming is not due to a spurious trend in the model but represents a natural decadal variability.

In the model Southern Hemisphere, the main areas of deep convection are found on the continental shelves. From late March to early August, during the period of maximum net freezing rates in these regions, typical convection depths in the southwestern Weddell and Ross Seas and in the Prydz Bay area are 250-300 m. Open ocean convection reaches maximum depths of $100 \mathrm{~m}$ in the Weddell Basin and $150 \mathrm{~m}$ in the Maud Rise area near the Greenwhich meridian. Furthermore, open ocean convection reaching down to a peak depth of $300 \mathrm{~m}$ for a short time in August is found east of Maud Rise. In this region, persistent upwelling due to a divergent surface drift causes shallowing of the mixed layer for most of the year. With the onset of freezing, salinity and thus surface density increases rapidly, leading to open ocean convection and the ventilation of the subsurface water column in this area.

Although mixing activity east of the Greenwhich meridian might be overestimated, hydrography in the Southern Ocean is reproduced rather realistically. Model sections through the Weddell Sea and the Atlantic sector of the Southern Ocean along the $45^{\circ} \mathrm{W}$ meridian indicate that regional hydrography is well captured even after 45 years of integration (Fig. 14). Specifically, the subsurface temperature maximum associated with the Warm Deep Water (WDW) is preserved, and the cold Weddell Sea Bottom Water (WSBW) is replenished. Mixing depths outside the centers of convective activity are underestimated with about $20 \mathrm{~m}$ in summer and $40 \mathrm{~m}$ in winter. Consequently, the model winter water layer is found at $40 \mathrm{~m}$ instead of $80 \mathrm{~m}$ depth. 

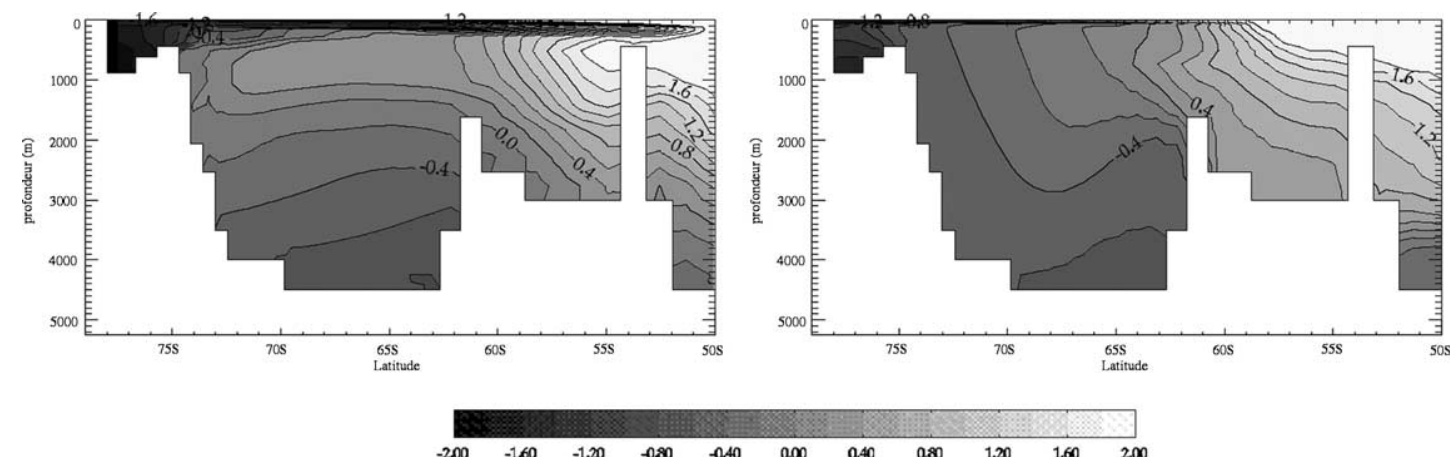

Fig. 14. Temperature sections along $45^{\circ} \mathrm{W}$ through the Weddell Sea and the Atlantic sector of the Southern Ocean up to $50^{\circ} \mathrm{S}$ for the initial state (left) and as an annual mean after 45 years of integration (right). Contour interval is $0.2^{\circ} \mathrm{C}$.

\section{Sensitivity experiments}

\subsection{All NCEP/NCAR daily forcing data}

In order to investigate whether the use of daily fields for all required atmospheric variables improves the representation of observed sea ice variability, we conducted a series of experiments in which not only the air temperature and wind speed but also specific humidity, total cloudiness, and precipitation were derived from the NCEP/NCAR daily reanalysis.

It turned out that a significant underestimation of ice coverage in both hemispheres is a robust feature in these simulations. While the seasonal mean Arctic sea ice extent is hardly affected (Fig. 15, left), the simulated Arctic sea ice volume is reduced by about $15 \%$ in winter and more than
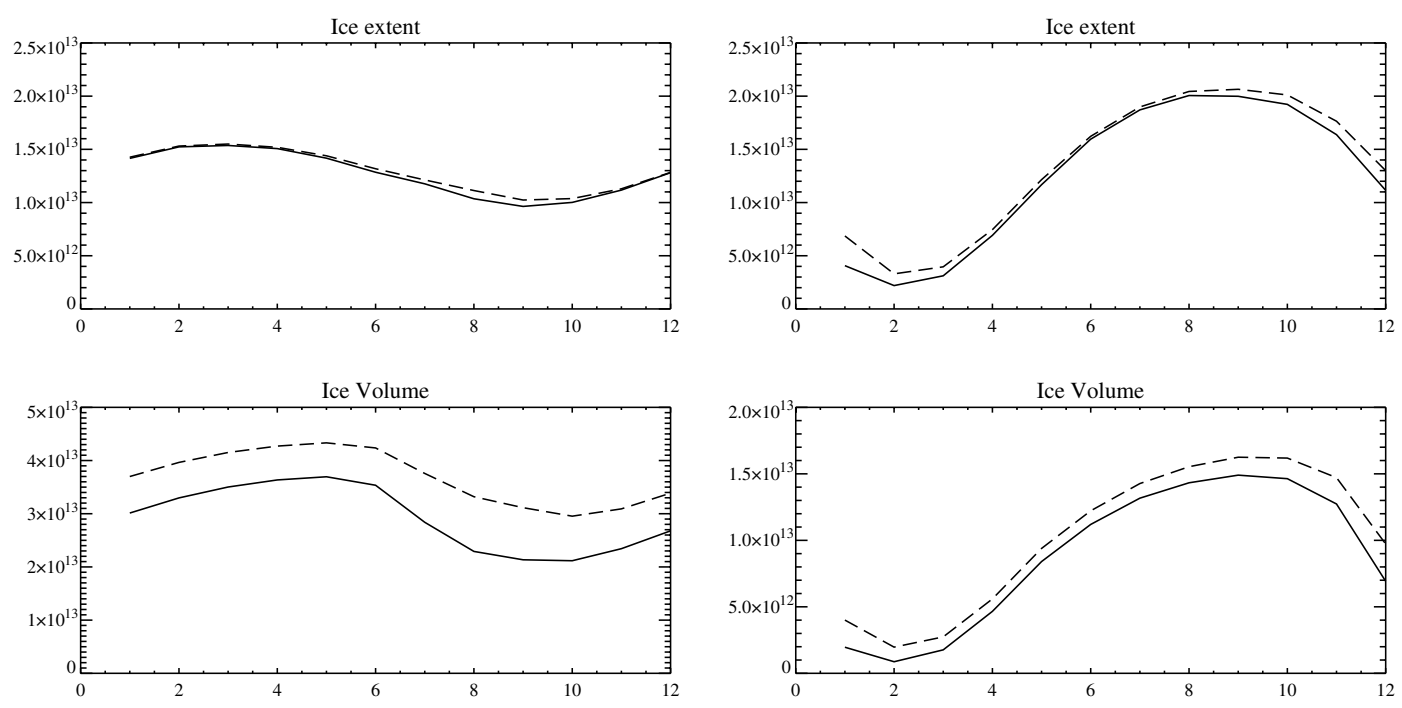

Fig. 15. Time series of seasonal mean Arctic (left) and Antarctic (right) sea ice extent $\left(\mathrm{m}^{2}\right)$ and volume $\left(\mathrm{m}^{2}\right)$ in an experiment with all NCEP/NCAR daily forcing data (solid) and in the ORCA2-LIM reference simulation (dashed). 
$25 \%$ in summer. Mean ice thickness is reduced by $1-1.5 \mathrm{~m}$ throughout the year, which in many cases leads to the formation of unrealistic open ocean polynyas in summer (Fig. 16, left).

In the Antarctic, ice volume is reduced by $10-15 \%$ in winter (Fig. 15, right). In summer, there is hardly any ice left (Fig. 16, right).

Further sensitivity experiments with different combinations of forcing datasets (not shown) indicate that the reduction of sea ice volume in the all-NCEP/NCAR simulation can be attributed to the specific humidity fields. The use of daily NCEP/NCAR data for wind speed, air temperature, cloudiness and precipitation (but not for specific humidity) leads to an increase of sea ice thickness in the Arctic and the southwestern Weddell Sea, while other parts of the Southern Ocean, including the Ross Sea and the central Weddell Sea, feature an ice thickness reduction of 20-50 $\mathrm{cm}$ compared to the reference experiment.

The representation of observed sea ice variability in this experiment is only slightly improved. Correlation coefficients between simulated and observed ice extent anomalies (Fig. 17) increase to 0.62 in the Arctic and to 0.52 in the Antarctic. However, the qualitative discrepancies in the late 1970s/early 1980s in the Arctic are not cured.

\subsection{NCEP/NCAR wind stress instead of wind speed}

An alternative strategy to obtain input data for the atmospheric wind stress in the sea ice momentum balance is to directly use the daily wind stress from the NCEP/NCAR reanalysis. Experiments using these data (instead of the wind speed and a quadratic bulk formula) feature very similar patterns with an even more pronounced Beaufort Gyre in the Arctic (Fig. 18), but compared to the analysis of Emery et al. (1997), ice drift speeds are overestimated by $50 \%$ and more. For regions with free drift, this could be cured by choosing a higher value for the ice-ocean drag coefficient, but the value of $c_{\mathrm{d}}^{\mathrm{io}}=5 \times 10^{-3}$ already is in the upper range of measurements.

Furthermore, a comparison with Quickscat data from 1999 (Cavanie, personal communication) indicates that monthly mean drift speeds in this experiment are overestimated by more than $100 \%$

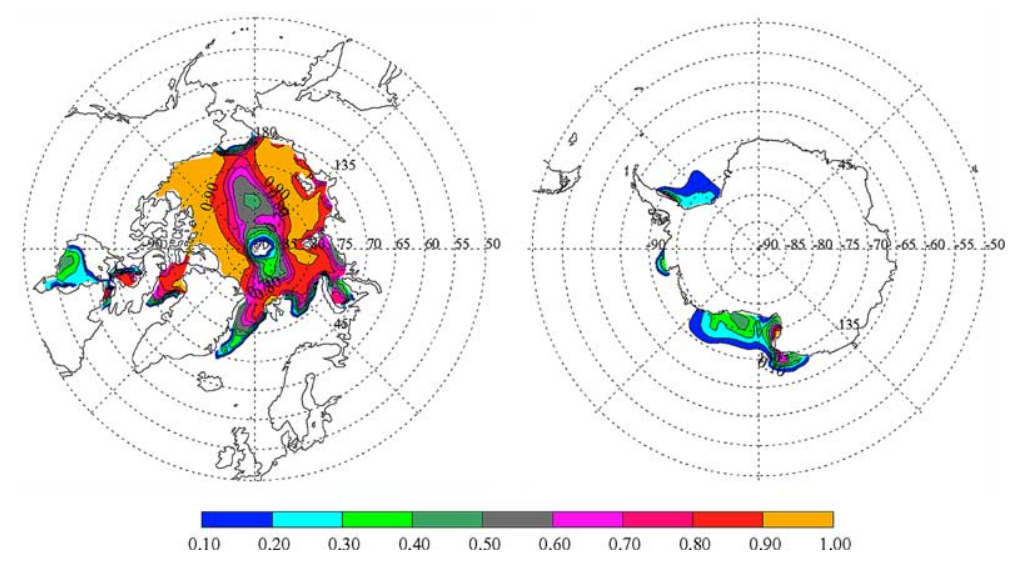

Fig. 16. Simulated summer ice concentrations for 1996 in the Arctic (left) and the Antarctic (right) in an experiment with all NCEP/NCAR forcing data. The year displayed was selected in order to provide a good example for the occurrence of a spurious open ocean polynya in the Arctic; results, however, are typical for many years. 

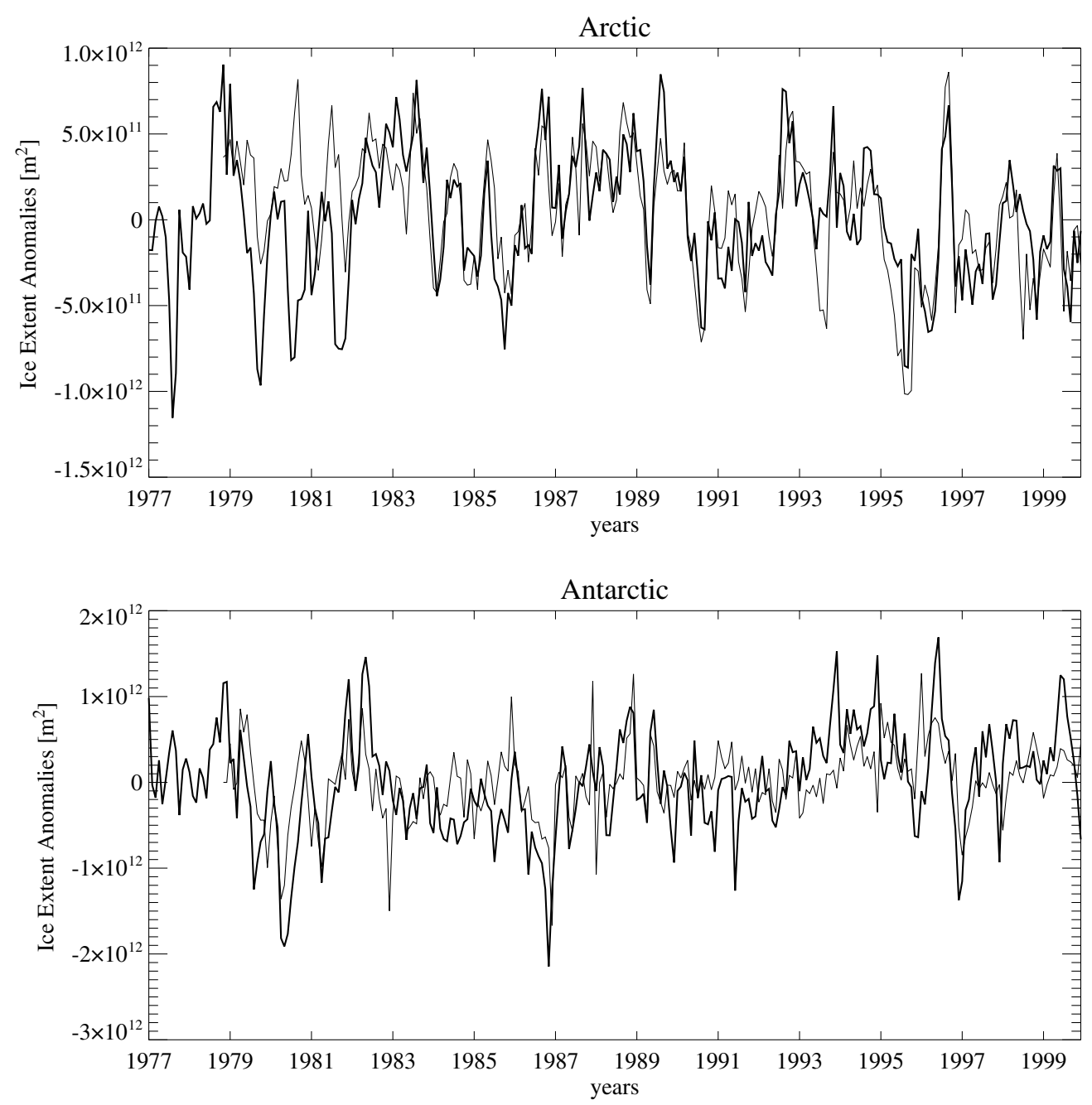

Fig. 17. Time series of monthly mean anomalies of sea ice extent $\left(\mathrm{m}^{2}\right)$ for the Arctic (top) and Antarctic (bottom) in the experiment using all NCEP/NCAR daily forcing (bold lines) and in observations derived from satellite passive microwave recordings (thin lines; Comiso, 1999; Heygster et al., 1996).

(Dulière, 2002). We conclude that directly using the NCEP/NCAR wind stress as input data for the sea ice momentum balance is not the ideal forcing strategy.

\subsection{No salinity restoring}

Experiments without sea surface salinity restoring indicate that this correction is necessary, especially in the Antarctic. While changes in simulated mixed layer depth are less than $100 \mathrm{~m}$ throughout the year in the Arctic (Fig. 19, left), mean winter convection depth in this experiment exceeds $2000 \mathrm{~m}$ in vast areas of the Southern Ocean (Fig. 19, right). This spurious open ocean 


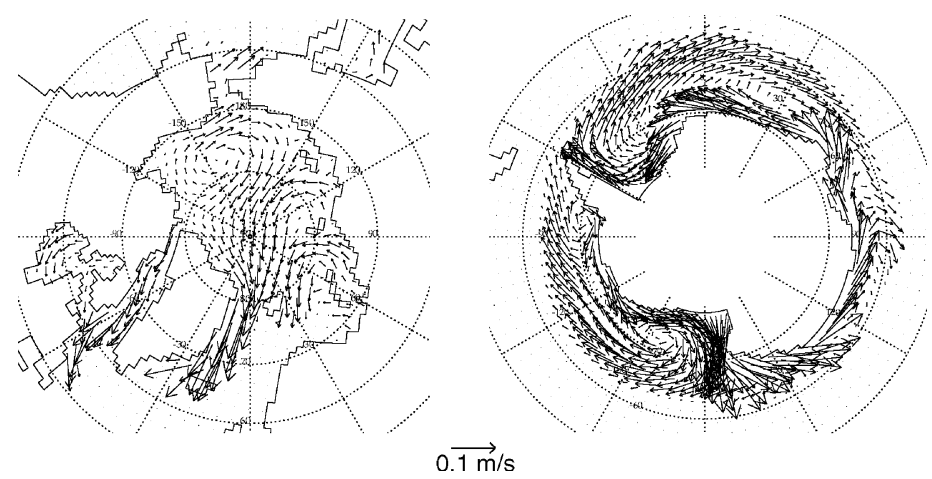

Fig. 18. Simulated mean sea ice velocities for the period 1988-1994 in the Arctic (left) and the Antarctic (right) in an experiment using the NCEP/NCAR wind speed to force the sea ice momentum balance.
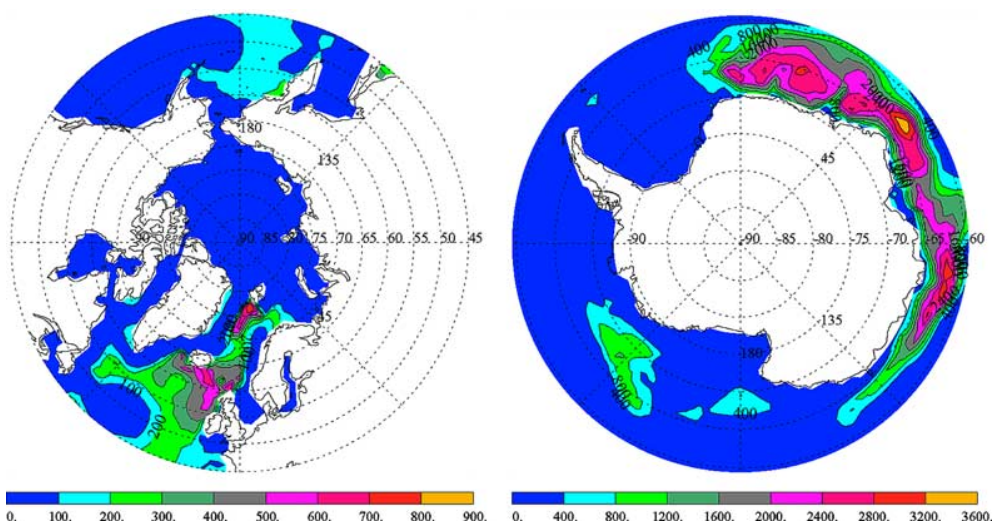

Fig. 19. Simulated mean winter mixed layer depths (as defined by the depth in which potential density exceeds surface density by more that $0.01 \mathrm{~kg} \mathrm{~m}^{-3}$ ) in an experiment with no restoring of the sea surface salinity, averaged over the first pass of the 1977-1999 forcing dataset. Contour intervals are $100 \mathrm{~m}$ for the Northern Hemisphere (left), and $400 \mathrm{~m}$ for the Southern Hemisphere (right).

convection leads to a vertical homogenization of the water column after only a few years of integration. Although the associated large upward heat flux does not lead to the formation of spurious open ocean polynyas, Southern Hemisphere ice volume is strongly reduced (Fig. 20). In the Arctic, ice extent and volume can hardly be distinguished from the reference experiment.

After 22 years of integration, most of the Southern Ocean basins are filled with a nearly homogeneous water mass with a potential temperature of about $-1{ }^{\circ} \mathrm{C}$. Density increase in the seasonally ice-covered seas increases the meridional density gradient and thus enhances the baroclinic component of the ACC. Consequently, net transport through Drake Passage increases to $220 \mathrm{~Sv}$. At this stage, the warm core of the WDW has been completely eroded; further convection thus cannot bring up large amounts of heat any more. Therefore, sea ice volume slowly recovers at the end of the integration; the ocean stratification, however, is not rebuilt. The Southern Ocean in this experiment thus remains in a highly unrealistic state. 

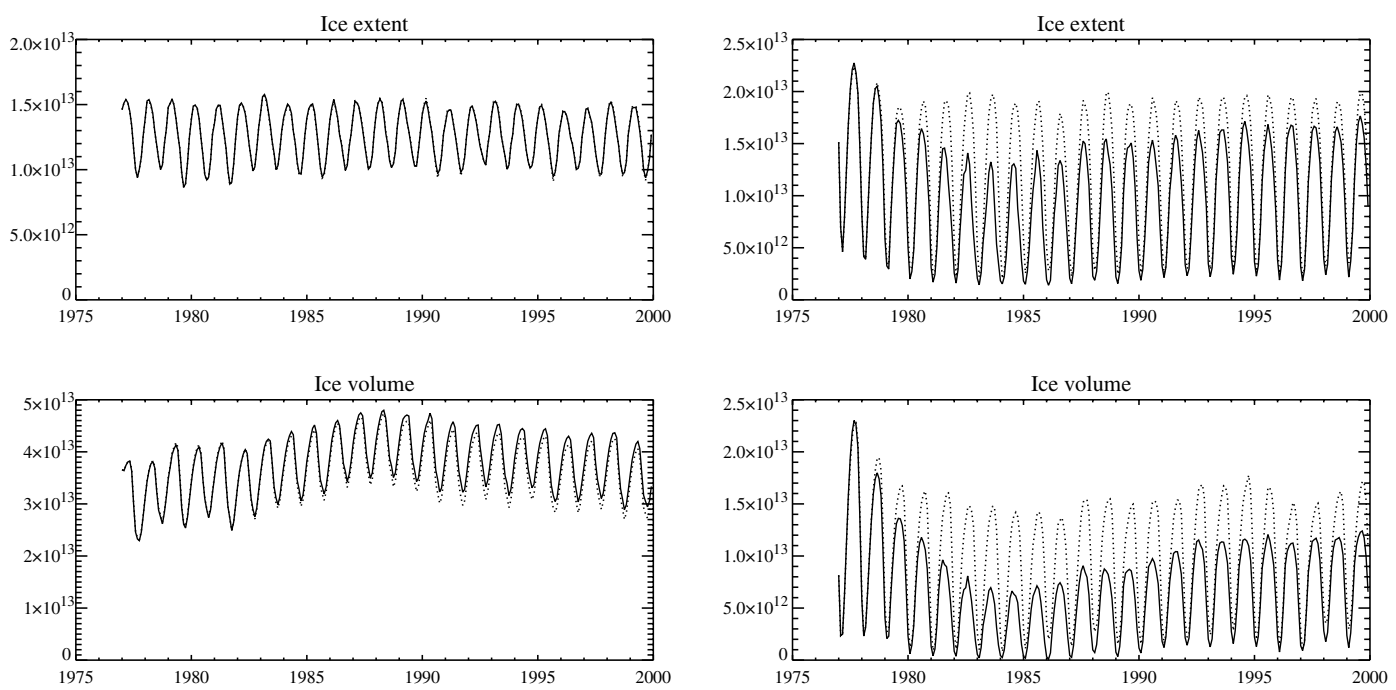

Fig. 20. Time series of Arctic (left) and Antarctic (right) sea ice extent $\left(\mathrm{m}^{2}\right)$ and volume $\left(\mathrm{m}^{3}\right)$ for the first 23 years of an experiment without SSS restoring (solid) and in the ORCA2-LIM reference simulation (dashed).

\section{Discussion and conclusions}

We have presented results from the ORCA2-LIM coupled sea ice-ocean model which has been optimized with respect to a good simulation of sea ice and ocean properties in the high latitudes of both hemispheres.

The model provides a rather realistic reproduction of the large-scale features of sea ice coverage in both hemispheres. In the Arctic, summer and winter ice extents agree well with observations derived from satellite passive microwave recordings. Interannual variability of sea ice extent, however, is only partly captured. Using daily varying fields for all atmospheric forcing data does not cure this deficiency. The simulated ice thicknesses and drifts are in good agreement with submarine ULS measurements - with a tendency towards overestimation of sea ice thicknessand the mean ice motion derived from $85.5 \mathrm{GHz}$ SSM/I data, respectively. The overestimation of sea ice export through Fram Strait is consistent with the apparent overestimation of ice thickness in the Arctic.

The modelled winter sea ice extent in the Antarctic is in good agreement with remote sensing data. The lack of multi-year ice and the related underestimation of summer sea ice extent in the northwestern Weddell Sea are attributed to a poor representation of the Antarctic Peninsula in the atmospheric forcing fields. The simulated sea ice thickness is underestimated in the western Weddell Sea but realistically captured further east and along the Greenwhich meridian. Deficiencies occur in regions featuring heavily deformed ice, specifically near the coast, which is partly due to resolution but also points towards a general underestimation of dynamic thickening in the model. Antarctic sea ice drift speed and patterns again agree very well with velocity fields derived from remote sensing data.

The hemispheric asymmetry of ice thickness errors with a tendency towards overestimation in the Arctic and underestimation in the Antarctic indicates that some critical process determining 
sea ice thickness is not yet fully covered. The introduction of a multi-category ice thickness distribution model following the ideas of Haapala (2000) is expected to yield a considerable improvement in the representation of regional-scale sea ice dynamics and thermodynamics (Vancoppenolle, personal communication).

Ocean circulation has been shown to be in reasonable agreement with observations and results from high-resolution ocean models, although the width of several currents (Arctic Ocean Boundary Current, Antarctic Circumpolar Current) is overestimated significantly. The introduction of a partial cells representation of bottom topography (Pacanowski and Gnanadesikan, 1998) in OPA version 8.5 and higher (Madec, personal communication) is expected to yield a better representation of topography-guided ocean currents.

The location of the main sites of deep convection (Labrador and Nordic Seas; continental shelves of marginal seas of the Southern Ocean) is well reproduced; convection depth is thoroughly reasonable. Thus, water mass properties compare well with observations even after several decades of integration. Subsurface warming in the Arctic Ocean might be overestimated but also represents a natural decadal variability.

These results are very sensitive to the choice of atmospheric boundary conditions and the experimental setup: Using the NCEP/NCAR daily reanalysis data for humidity, cloudiness and precipitation slightly improves the representation of observed sea ice variability but yields a significant reduction in ice volume and an underestimation of summer ice coverage in both hemispheres; using the NCEP/NCAR surface stress instead of the wind field yields a significant overestimation of ice drift speed. A smaller lead closing parameter leads to an underestimation of especially the Antarctic sea ice thickness. Abandoning the SSS restoring leads to a rapid homogenization of the water column in the marginal seas of the Southern Ocean and an associated loss in ice volume, while employing a shorter restoring time scale quickly reduces bottom water formation rates.

Although we have pointed out a number of regional deficiencies in the reference simulation, one has to bear in mind that the model has a mean resolution of $2^{\circ}$ and thus cannot capture all the details of observed sea ice coverage. None of the shortcomings discussed is likely to cause significant changes in the global impact of the high latitude oceans. The absence of a numerically induced trend in the sea ice coverage allows long-term integrations as well as investigations of interannual variability. We conclude that, although several limitations should be kept in mind, the ORCA2-LIM version presented above is an appropriate tool not only for studies of the large-scale to global ocean circulation but also for the investigation of regional processes and phenomena in high latitudes.

\section{Acknowledgements}

The NCEP/NCAR reanalysis data were provided by the National Oceanic and Atmospheric Administration-Cooperative Institute for Research in Environmental Sciences Climate Diagnostics Center, Boulder, online at http://www.cdc.noaa.gov. Interpolation of temperature data to the ORCA2 grid was done by K. Rodgers. The Bootstrap sea-ice data were obtained through the National Snow and Ice Data Center, University of Colorado, Boulder. Thanks to J. Lieser for providing us with a ready-to-use mapping script and to K. Assmann for helpful discussions about 
sea ice the RAB Seas sector. Comments from two anonymous reviewers helped to improve the manuscript. T. Fichefet and H. Goosse are Research Associates with the Belgian National Fund for Scientific Research. This study was carried out as part of the Second Multiannual Scientific Support Plan for a Sustainable Development Policy (Belgian State, Prime Minister's Services, Federal Office for Scientific, Technical, and Cultural Affairs, contracts EV/10/7D and EV/10/9A), the French project of operational oceanography MERCATOR, and the Action Concertée Initiative Changement Climatique (project "Changement climatique et cryosphère"), Ministère Francais de la Recherche. Support from each of these is gratefully acknowledged.

\section{References}

Barthelet, P., Terray, L., Valcke, S., 1998. Transient $\mathrm{CO}_{2}$ experiment using the ARPEGE/OPAICE non-flux corrected coupled model. Geophysical Research Letters 25, 2277-2280.

Baumgartner, A., Reichel, E., 1975. The World Water Balance, Mean Annual Global, Continental and Maritime Precipitation, Evaporation and Runoff. Elsevier. p. 179.

Beckmann, A., Döscher, R., 1997. A method for improved representation of dense water spreading over topography in geopotential-coordinate models. Journal of Physical Oceanography 27 (4), 581-591.

Berliand, M.E., Strokina, T.G., 1980. Global Distribution of the Total Amount of Clouds. Hydrometeorological, Leningrad, 71 pp. (in Russian).

Blanke, B., Delecluse, P., 1993. Low frequency variability of the tropical Atlantic ocean simulated by a general circulation model with mixed layer physics. Journal of Physical Oceanography 23, 1363-1388.

Bougeault, P., Lacarrère, P., 1989. Parameterization of orography-induced turbulence in a mesobeta-scale model. Monthly Weather Review 117, 1872-1890.

Bourke, R.H., Garrett, R.P., 1987. Sea ice thickness distribution in the Arctic ocean. Cold Regions Science and Technology 13, 259-280.

Bourke, R.H., McLaren, A.S., 1992. Contour mapping of Arctic Basin ice draft and roughness parameters. Journal of Geophysical Research 97 (C11), 17715-17728.

Braconnot, P., Joussaume, S., Marti, O., de Noblet, N., 1999. Synergistic feedbacks from ocean and vegetation on the African monsoon response to mid-Holocene insolation. Geophysical Research Letters 26, 2481-2484.

Carmack, E.C., MacDonald, R.W., Perkin, R.G., McLaughlin, F.A., Pearson, R.J., 1995. Evidence for warming of Atlantic water in the southern Canadian Basin of the Arctic Ocean: Results from the Larsen-93 expedition. Geophysical Research Letters 22, 1061-1064.

Cavalieri, D.J., Parkinson, C.L., Gloersen, P., Zwally, H.J., 1999. Sea ice concentrations from Nimbus-7 SMMR and DMSP SSM/I passive microwave data. Technical Report, National Snow and Ice Data Center, Boulder, CO.

Comiso, J., 1999 updated 2002. Bootstrap sea ice concentrations for NIMBUS-7 SMMR and DMSP SSM/I. National Snow and Ice Data Center, Boulder, CO, USA. Digital media.

Comiso, J.C., Cavalieri, D.J., Parkinson, C.L., Gloersen, P., 1997. Passive microwave algorithm for sea ice concentration: a comparison of two techniques. Remote Sensing of Environment 60, 357-384.

Comiso, J.C., Wadhams, P., Pedersen, L.T., Gersten, R.A., 2001. Seasonal and interannual variability of the Odden ice tongue and a study of environmental effects. Journal of Geophysical Research 106, 9093-9116.

Cunningham, S.A., Alderson, S.G., King, B.A., Brandon, M.A., 2003. Transport and variability of the Antarctic Circumpolar Current in drake passage. Journal of Geophysical Research 108 (C5), doi:10.1029/2001JC001147.

Dulière, V., 2002. ORCALIM2, un nouveau modèle couplé océan-glace de mer. Rapport de recherche, Université catholique de Louvain, Louvain-la-Neuve, Belgium, 43 pp.

Emery, W.J., Fowler, C.W., Maslanik, J.A., 1997. Satellite-derived maps of Arctic and Antarctic sea ice motion: 19881994. Geophysical Research Letters 24 (8), 897-900.

Fahrbach, E., Rohardt, G., Schröder, M., Strass, V., 1994. Transport and structure of the Weddell Gyre. Annales Geophysicae 12, 840-855. 
Fichefet, T., Morales Maqueda, M.A., 1997. Sensitivity of a global sea ice model to the treatment of ice thermodynamics and dynamics. Journal of Geophysical Research 102 (C6), 12609-12646.

Fichefet, T., Morales Maqueda, M.A., 1999. Modelling the influence of snow accumulation and snow-ice formation on the seasonal cycle of the Antarctic sea-ice cover. Climate Dynamics 15, 251-268.

Fichefet, T., Tartinville, B., Goosse, H., 2003a. Antarctic sea ice variability during 1958-1999: a simulation with a global ice-ocean model. Journal of Geophysical Research 108 (C3), 1913, doi:10.1029/2001JC001148.

Fichefet, T., Goosse, H., Morales Maqueda, M.A., 2003b. A hindcast simulation of the Arctic and Antarctic sea-ice variability, 1955-2001. Polar Research 22 (1), 91-98.

Friedlingstein, P., Bopp, L., Ciais, P., Dufresne, J.-L., Fairhead, L., LeTreut, H., Monfray, P., Orr, J., 2001. Positive feedback between future climate change and the carbon cycle. Geophysical Research Letters 28 (8), 1543-1546.

Gaspar, P., Grégoris, Y., Lefevre, J.-M., 1990. A simple eddy-kinetic-energy model for simulations of the oceanic vertical mixing: tests at Station Papa and Long-Term Upper Ocean Study Site. Journal of Geophysical Research 95, 16179-16193.

Gent, P.R., McWilliams, J.C., 1990. Isopycnal mixing in ocean circulation models. Journal of Physical Oceanography $20,150-155$.

Gerdes, R., Karcher, M.J., Kauker, F., Schauer, U., 2003. Causes and development of repeated Arctic Ocean warming events. Geophysical Research Letters 30 (19), 1980, doi:10.1029/2003GL018080.

Goosse, H., 1997. Modelling the large-scale behaviour of the coupled ocean-sea-ice system. Ph.D. Thesis, Université Catholique de Louvain, Louvain-la- Neuve, Belgium, 231 pp.

Goosse, H., Fichefet, T., 1999. Importance of ice-ocean interactions for the global ocean circulation: a model study. Journal of Geophysical Research 104, 23337-23355.

GRDC (Global Runoff Data Centre)/Max Planck Institute, 2000. Observed historical discharge data from major rivers for climate model validation. Report first published in 1993, updated in 2000. Report and data available from <www.mpimet.mpg.de/deutsch/Sonst/Reports/HTMLReports> and <www.bafg.de/grdc.htm>.

Greenfell, T.C., Perovich, D.K., 1984. Spectral albedos of sea ice and incident solar irradiance in the southern Beaufort Sea. Journal of Geophysical Research 89, 3573-3580.

Guilyardi, E., Madec, G., Terray, L., 2001. The role of lateral ocean physics in the upper ocean thermal balance of a coupled ocean-atmosphere GCM. Climate Dynamics 17, 589-599.

Häkkinen, S., 1995. Seasonal simulation of the Southern Ocean coupled ice-ocean system. Journal of Geophysical Research 100 (C11), 22733-22748.

Häkkinen, S., Mellor, G.L., 1992. Modeling the seasonal variability of a coupled Arctic ice-ocean system. Journal of Geophysical Research 97 (C12), 20285-20304.

Haapala, J., 2000. On the modelling of the ice thickness redistribution. Journal of Glaciology 46, 427-437.

Harder, M., Lemke, P., 1994. Modelling the extent of sea ice ridging in the Weddell Sea. In: The Polar Oceans and their Role in Shaping the Global Environment Geophysical Monograph, vol. 85. AGU, Washington, USA, pp. 187-197.

Harms, S., Fahrbach, E., Strass, V.H., 2001. Sea ice transports in the Weddell Sea. Journal of Geophysical Research 106 (C5), 9057-9074.

Heil, P., Hibler III, W.D., 2002. Modelling the high-frequency component of Arctic sea-ice drift and deformation. Journal of Physical Oceanography 32 (11), 3039-3057.

Heygster, G., Pedersen, L., Turner, J., Thomas, C.H., Hunewinkel, T., Schottmueller, H., Viehoff, T., 1996. PELICON: project for estimation of longterm variability of ice concentration. Technical Report Contract EV5V-CT930268(DG 12 DTEE), European Community.

Hibler III, W.D., 1979. A dynamic thermodynamic sea ice model. Journal of Physical Oceanography 9 (4), 815-846.

Jackett, D.R., McDougall, T.J., 1995. Stabilization of hydrographic data. Journal of Atmospheric and Oceanic Technology 12, 381-389.

Jacobs, S.S., Comiso, J.C., 1989. Sea ice and oceanic processes on the Ross Sea continental shelf. Journal of Geophysical Research 94, 18195-18211.

Kalnay, E., Kanamitsu, M., Kistler, R., Collins, W., Deaven, D., Gandin, L., Iredell, M., Saha, S., White, G., Woollen, J., Zhu, Y., Chelliah, M., Ebisuzaki, W., Higgins, W., Janowiak, J., Mo, K.C., Ropelewski, C., Wang, J., Leetmaa, A., Reynolds, R., Jenne, R., Joseph, D., 1996. The NCEP/NCAR 40-year reanalysis project. Bulletin of the American Meteorological Society 77, 437-471. 
Kim, S.-J., Stössel, A., 1998. On the representation of the Southern Ocean water masses in an ocean climate model. Journal of Geophysical Research 103 (C11), 24891-24906.

Kwok, R., Rothrock, D.A., 1999. Variability of Fram Strait Ice flux and the North Atlantic oscillation. Journal of Geophysical Research 104 (C3), 5177-5190.

Madec, G., Delecluse, P., Imbard, M., Lévy, C., 1999. OPA 8.1 Ocean General Circulation Model reference manual. Notes du Pôle de modélisation, Institut Pierre-Simon Laplace (IPSL), France, X, 91 pp.

Marsland, S., Wolff, J.-O., 2001. On the sensitivity of Southern Ocean sea ice to the surface freshwater flux: a model study. Journal of Geophysical Research 106 (C2), 2723-2741.

McPhee, M.G., 1992. Turbulent heat flux in the upper ocean under sea ice. Journal of Geophysical Research 97, 53655379 .

Merryfield, W.J., Holloway, G., Gargett, A.E., 1999. A global ocean model with double-diffusive mixing. Journal of Physical Oceanography 29, 1124-1142.

Pacanowski, R.C., Gnanadesikan, A., 1998. Transient response in a $z$-level ocean model that resolves topography with partial cells. Monthly Weather Review 126, 3248-3270.

Parkinson, C.L., Cavalieri, D.J., Gloersen, P., Zwally, H.J., Comiso, J.C., 1999. Arctic sea ice extents, area, and trends, 1978-1996. Journal of Geophysical Research 104 (C9), 20837-20856.

Prather, M.C., 1986. Numerical advection by conservation of second-order moments. Journal of Geophysical Research 91, 6671-6681.

Raynaud, S., Speich, S., Guilyardi, E., Madec, G., 2000. Impacts of the ocean lateral diffusion on the El Niño/Southern Oscillation-like variability of a global coupled general circulation model. Geophysical Research Letters 27, 30413044.

Roach, A.T., Aagaard, K., Pease, C.H., Salo, S.A., Weingartner, T., Pavlov, V., Kulakov, M., 1995. Direct measurements of transport and water properties through Bering Strait. Journal of Geophysical Research 100, 18443-18457.

Rothrock, D.A., Zhang, J., Yu, Y., 2003. The arctic ice thickness anomaly of the 1990s: a consistent view from observations and models. Journal of Geophysical Research 108 (C3), doi:10.1029/2001JC001208.

Schröder, M., Fahrbach, E., 1999. On the structure and the transport of the eastern Weddell Gyre. Deep Sea Research II $46,501-527$.

Shine, K.P., Henderson-Sellers, A., 1985. The sensitivity of a thermodynamic sea ice model to changes in surface albedo parameterization. Journal of Geophysical Research 90, 2243-2250.

Smith, W.H.F., Sandwell, D.T., 1997. Global sea floor topography from satellite altimetry and ship depth soundings. Science 277, 1956-1962.

Steele, M., Morley, R., Ermold, W., 2001. PHC: a global ocean hydrography with a high quality Arctic Ocean. Journal of Climate 14, 2079-2087.

Stern, H.L., Rothrock, D.A., Kwok, R., 1995. Open water production in Arctic sea ice: satellite measurements and model parametrizations. Journal of Geophysical Research 100 (C10), 20601-20612.

Strass, V.H., Fahrbach, E., 1998. Temporal and regional variation of sea ice draft and coverage in the Weddell Sea obtained from Upward Looking Sonars. In: Jeffries, M.O. (Ed.), Antarctic Sea Ice: Physical Processes, Interactions and Variability. In: Antarctic Res. Ser., vol. 74, pp. 123-139.

Timmermann, R., Beckmann, A., Hellmer, H.H., 2002a. Simulation of ice-ocean dynamics in the Weddell Sea. Part I: Model configuration and validation. Journal of Geophysical Research 107 (C3), doi:10.1029/2000JC000741.

Timmermann, R., Hellmer, H.H., Beckmann, A., 2002b. Simulation of ice-ocean dynamics in the Weddell Sea. Part II: Interannual variability 1985-1993. Journal of Geophysical Research 107 (C3), doi:10.1029/2000JC000742.

Trenberth, K.E., Olson, J.G., Large, W.G., 1989. A global ocean wind stress climatology based on the ECMWF analyses. National Center for Atmospheric Research, Boulder, NCAR/TN-338+STR, 93 pp.

Tucker III, W.B., Weatherly, J.W., Eppler, D.T., Farmer, D., Bentley, D.L., 2001. Evidence for the rapid thinning of sea ice in the western Arctic Ocean at the end of the 1980s. Geophysical Research Letters 28 (14), 2851-2854.

Vialard, J., Menkes, C., Boulanger, J.-P., Delecluse, P., Guilyardi, E., McPhaden, M.J., Madec, G., 2001. A model study of oceanic mechanisms affecting equatorial Pacific sea surface temperature 1997-98 El Niño. Journal of Physical Oceanography 31, 1649-1675.

Vinje, T., 2001. Fram Strait ice fluxes and atmospheric circulation: 1950-2000. Journal of Climate 14 (16), 3508-3517. 
Whitworth III, T., Peterson, R.G., 1985. The volume transport of the Antarctic Circumpolar Current from three-year bottom pressure measurements. Journal of Physical Oceanography 15, 810-816.

Windmüller, M., 1997. Untersuchung von atmosphärischen Reanalysedaten im Weddellmeer und Anwendung auf ein dynamisch thermodynamisches Meereismodell. Diplomarbeit am Institut für Meereskunde an der ChristianAlbrechts-Universität, Kiel, Germany, 65 pp.

Xie, P., Arkin, P.A., 1996. Analyses of global monthly precipitation using gauge observations, satellite estimates and numerical model predictions. Journal of Climate 9, 840-858.

Zhang, Y.X., Semtner, A.J., 2001. The Antarctic Circumpolar Wave in a global, high-resolution, coupled ice-ocean model. Annals of Glaciology 33, 539-544.

Zhang, J., Hibler, W., Steele, M., Rothrock, O., 1998. Arctic ice-ocean modeling with and without climate restoring. Journal of Physical Oceanography 28, 191-217.

Zhang, Y., Maslowski, W., Semtner, A.J., 1999. Impact of mesoscale ocean currents on sea ice in high-resolution Arctic ice and ocean simulations. Journal of Geophysical Research 104 (C8), 18409-18429. 